\title{
Towards decision-based global land use models for improved understanding of the Earth system
}

\author{
M. D. A. Rounsevell ${ }^{1}$, A. Arneth ${ }^{2}$, P. Alexander ${ }^{1}$, D. G. Brown ${ }^{3}$, N. de Noblet-Ducoudré ${ }^{4}$, E. Ellis ${ }^{5}$, J. Finnigan ${ }^{6}$,

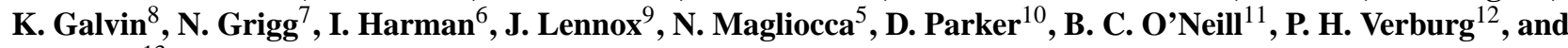 \\ O. Young ${ }^{13}$ \\ ${ }^{1}$ School of GeoSciences, University of Edinburgh, Edinburgh, UK \\ ${ }^{2}$ Karlsruhe Institute of Technology, Institute of Meteorology and Climate Research/Atmospheric Environmental Research, \\ Garmisch-Partenkirchen, Germany \\ ${ }^{3}$ School of Natural Resources and Environment, University of Michigan, Ann Arbor, MI, USA \\ ${ }^{4}$ Laboratoire des Sciences du Climat et de l'Environnement, Unité mixte CEA-CNRS-UVSQ, Gif-sur-Yvette, France \\ ${ }^{5}$ Department of Geography and Environmental Systems, University of Maryland, Baltimore County, MD, USA \\ ${ }^{6}$ The Centre for Australian Weather and Climate Research - A partnership between CSIRO and the Bureau of Meteorology, \\ CSIRO Marine and Atmospheric Research, Canberra, Australia \\ ${ }^{7}$ CSIRO Land and Water, Canberra, Australia \\ ${ }^{8}$ Department of Anthropology, Colorado State University, Fort Collins, CO, USA \\ ${ }^{9}$ Fondazione Eni Enrico Mattei (FEEM), Venice, Italy \\ ${ }^{10}$ School of Planning, Faculty of Environment, University of Waterloo, Waterloo, Canada \\ ${ }^{11}$ Climate and Global Dynamics Division \& Integrated Science Program, National Center for Atmospheric Research (NCAR), \\ Boulder, CO, USA \\ ${ }^{12}$ Institute for Environmental Studies, Amsterdam Global Change Institute, VU University Amsterdam, \\ Amsterdam, the Netherlands \\ ${ }^{13}$ Bren School of Environmental Science \& Management, University of California, Santa Barbara, CA, USA
}

Correspondence to: M. D. A. Rounsevell (mark.rounsevell@ed.ac.uk)

Received: 9 July 2013 - Published in Earth Syst. Dynam. Discuss.: 27 August 2013

Revised: 10 January 2014 - Accepted: 12 January 2014 - Published: 26 February 2014

\begin{abstract}
A primary goal of Earth system modelling is to improve understanding of the interactions and feedbacks between human decision making and biophysical processes. The nexus of land use and land cover change (LULCC) and the climate system is an important example. LULCC contributes to global and regional climate change, while climate affects the functioning of terrestrial ecosystems and LULCC. However, at present, LULCC is poorly represented in global circulation models (GCMs). LULCC models that are explicit about human behaviour and decision-making processes have been developed at local to regional scales, but the principles of these approaches have not yet been applied to the global scale level in ways that deal adequately with both direct and indirect feedbacks from the climate system. In this article, we explore current knowledge about LULCC modelling and
\end{abstract}

the interactions between LULCC, GCMs and dynamic global vegetation models (DGVMs). In doing so, we propose new ways forward for improving LULCC representations in Earth system models. We conclude that LULCC models need to better conceptualise the alternatives for upscaling from the local to global scale. This involves better representation of human agency, including processes such as learning, adaptation and agent evolution, formalising the role and emergence of governance structures, institutional arrangements and policy as endogenous processes and better theorising about the role of teleconnections and connectivity across global networks. Our analysis underlines the importance of observational data in global-scale assessments and the need for coordination in synthesising and assimilating available data. 


\section{Introduction}

Land use and land cover change (LULCC) is one of the key processes through which humans affect the functioning of the Earth system, contributing to global environmental change and its impacts on the provision of ecosystem services and human wellbeing (Turner II et al., 2007; Foley et al., 2005). The land system plays a fundamental role in supplying the global population with ecosystem services, including food (Brown and Funk, 2008; Fischer et al., 2005; Lobell et al., 2008), fresh water (Gerten et al., 2005), biogeochemical and biophysical climate regulation (Le Quere et al., 2009; Betts, 2000; Friedlingstein et al., 2006) and biodiversity (De Chazal and Rounsevell, 2009). The quantity and quality of ecosystem services supplied from land are responsive to climate change and human management in complex ways. Thus, better understanding of the interplay between land use, ecosystems and the global Earth system is likely to support the development of sustainable land management strategies. Current models of the climate and human systems lack, however, a level of development that is necessary to account for this complex interplay.

LULCC affects climate regionally, i.e. via changes in albedo and surface energy partitioning (Pitman et al., 2009; de Noblet-Ducoudré et al., 2012), and globally, i.e. via emissions and uptake of long-lived greenhouse gases (GHG) (Le Quere et al., 2009). In climate models, human activities have been considered, if at all, as external drivers that provide the emissions necessary for climate or atmospheric chemistry simulation experiments, ignoring the possibility that anthropogenic activities not only affect the Earth system but also in turn respond to system changes. As well as LULCC effects on climate, LULCC is affected by climate change both locally and regionally. For instance, climate can affect the physical suitability or economic viability of an agricultural crop in a region (Lobell et al., 2011; Gornall et al., 2010). It is less well recognised, however, that land use decisions at one location, regardless of whether they are driven by changes in the climate, economy or policy, may affect land use decisions elsewhere (Melillo et al., 2009; Tilman et al., 2011; Godfray et al., 2010; Seto et al., 2012) through a large variety of teleconnections (e.g. economics, atmospheric pollution). Hence, LULCC needs to go beyond the "local" and be understood from a global perspective.

The mechanisms through which changes in the climate or biophysical/biogeochemical processes affect societal behaviour and individual and institutional response strategies, and vice versa, have so far not been addressed in global-scale models leaving human teleconnections affecting LULCC largely unanalysed. Integrated assessment models (IAMs) that combine representations of the economic, social and natural system struggle to fulfil this role since they are top-down models that are insufficiently resolved to facilitate process understanding across the full spectrum of spatial scales and actors involved in LULCC (Verburg et al., 2012). There is clearly a need to make progress in linking terrestrial and climate system models that include representation of ecosystem management, with models of human dynamics that reflect behaviour and decision processes at multiple spatial and organisational scales.

Existing global-scale models of human systems do not yet account for diversity in the types of human behaviour processes, decision-making strategies and governance structures that are known to underpin the human components of Earth system functioning. IAMs represent the globe using variations among regions (of the order of 15-150) and sectors (Lawrence and Chase, 2010; Strengers et al., 2010; Verburg et al., 2012), while at the local (landscape) scale, information about the goals, motivations and behaviours of land use actors is collected through social surveys, behavioural experiments, role-playing games and participant observation (Robinson et al., 2007), These local-scale insights are translated into computational agent-based models (ABMs) (Parker et al., 2003; Murray-Rust et al., 2011; Matthews et al., 2007; Bousquet and Le Page, 2004) that represent human behaviour and decision processes within the land system. Though ABMs could, in principle, be adapted to larger spatial domains, e.g. globally, this has not yet been attempted in practice. If realised, such an approach would allow pertinent questions to be addressed about the relative effects of socioeconomic decision making versus climate change on LULCC in a globalised world; furthermore, it would allow feedbacks between climate change and land use decision making to be identified.

We review and discuss current knowledge about LULCC and its interactions with the climate system and how these processes are represented in models. In doing so, we identify research gaps and propose ways forward for the next generation of Earth system models. The discussion tackles two fundamental research questions: how can we better represent the land system in Earth system models? How can we improve models of the global land system by better representing human behaviour and decision-making processes? We hypothesise that addressing decision-making structures explicitly within global change assessments will improve the analysis of alternative future development pathways under global change assumptions. Figure 1 schematically represents the major components of the land and climate systems and their respective interactions that are addressed in this article.

\section{LULCC and climate system relationships}

\subsection{LULCC influences on the climate system}

Between 30 and $50 \%$ of the land surface today has been transformed as a result of human activities. Conversion of natural ecosystems into cropland and pastures, mostly through deforestation, has led to an estimated release of more than $150 \mathrm{PgC}$ into the atmosphere, one-third of the 


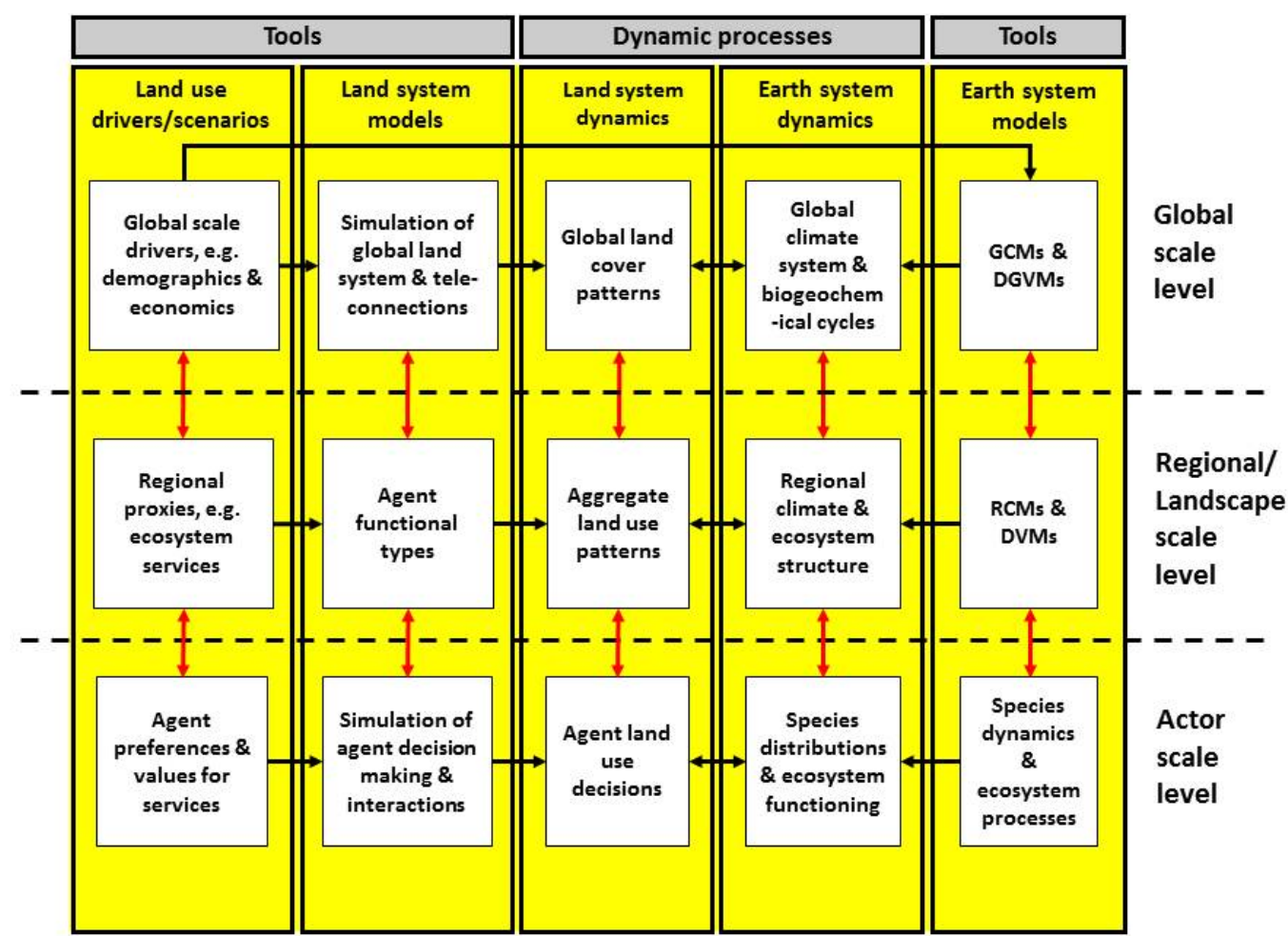

$\lceil$ Red arrows indicate aggregation and disaggregation; $\longleftrightarrow$ Black arrows indicate impacts, influences and feedbacks

Fig. 1. Schematic representation of the components of the land and climate systems discussed here at different spatial scale levels.

approximate total anthropogenic carbon emissions since 1850 (Houghton, 2003; Le Quere et al., 2009). LULCC can also mitigate global climate impacts, since reforestation, afforestation or avoided deforestation can either increase the carbon sink strength of land or prevent additional C emissions to the atmosphere. Historically, LULCC has contributed strongly to climate warming (Le Quere et al., 2009), since the $\mathrm{CO}_{2}$ emissions arising from past LULCC activities to the atmosphere have exceeded LULCC-related land carbon sinks. Around half of the observed increase in atmospheric $\mathrm{N}_{2} \mathrm{O}$ over the same time period has been attributed to the use of agricultural fertiliser arising from LULCC (Zaehle et al., 2011).

The climate effects arising from changes in terrestrial biogeochemical processes that affect sources and sinks of carbon- and nitrogen-containing GHGs continue to operate over centuries because these gases are long-lived in the atmosphere and because changes in vegetation and soil $\mathrm{C}$ and $\mathrm{N}$ pools operate over decades and centuries. The biogeochemical climate effects are both regional and global in nature. Human-mediated changes such as crop production also affect biophysical exchange processes at the land surface. For instance, conversion of forest into crop vegetation decreases both surface roughness and mixing of the near-surface air (surface warming), increases the fraction of radiation reflected back into the atmosphere (surface cooling), and changes the partitioning of the net radiation received at the surface into evapotranspiration (latent heat flux) and sensible heat flux (warming or cooling, depending on the ratio of latent to sensible heat flux). Extreme weather episodes, such as altered monsoon patterns and the occurrence of droughts, have also been linked to biophysical LULCC processes (Schubert et al., 2004; Cui et al., 2006).

The direct biogeophysical radiative impact of LULCC since pre-industrial times has been estimated to have reduced the global average radiative forcing by $0.2 \pm 0.2 \mathrm{~W} \mathrm{~m}^{-2}$, which is small compared with the biogeochemical radiative impact of LULCC and other global climate forcings (Forster et al., 2007). Compared to biogeochemical effects, biophysical climate effects are expected to be stronger regionally and realised over a period of a few months to several decades following a LULCC event (Pitman et al., 2009; Arora and Montenegro, 2011 ), since the initial changes in land cover tend to have the strongest effects on the surface radiation and energy balances. Moreover, the direction of the net biophysical effects in terms of exerting a warming or cooling depends on the existing climate, vegetation and soil states, and varies regionally (Arora and Montenegro, 2011).

A number of observational studies support the major role of LULCC in altering surface fluxes and boundary layer 
dynamics (e.g. Kala et al., 2011; Lobell and Bonfils, 2008; Lim et al., 2005). Where LULCC has been intensive, the regional impact is likely to be at least as important as GHG and aerosol forcing (Boisier et al., 2012; de Noblet-Ducoudré et al., 2012; Lawrence and Chase, 2010). These regional LULCC-climate interactions are therefore important, as the essential resources of food, water, energy, human health and ecosystem function respond to regional and local climate, and not to a global average. Human vulnerability to forcings such as climate change is realised locally and regionally, and the conclusion that LULCC is a significant regionalscale driver of climate is sufficient to require its incorporation into past, present and future climate model simulations, not least for the development of local mitigation or adaptation strategies.

Quantifying the LULCC-related combined biogeochemical and biophysical climate effects is challenging, since they can either amplify (both warming or cooling) or compensate (one warming, one cooling) one another (Pitman et al., 2009; Arora and Montenegro, 2011; de Noblet-Ducoudré et al., 2012). Indeed there is no consensus about which metric to use when assessing land-climate interactions. Topof-the-atmosphere radiative forcing, often used in climate change science, is not a complete measure (Davin et al., 2007; Davin and de Noblet-Ducoudré, 2010) and there is strong contingency on location, scale and existing climate of land-climate system interactions. Although the biogeochemical and biophysical impacts of LULCC have been studied increasingly in recent years, this has mostly been done in separate studies, with the combined, net effect of both on climate addressed only in a few exceptional cases (Brovkin et al., 2004, 2006; Sitch et al., 2005). Given the large impact of LULCC on regional and/or global climates, and the difficulties in quantifying the relative roles of biogeochemical vs. biophysical LULCC-related climate impacts, the rather rudimentary treatment of LULCC processes in Earth system models (ESMs) and their land surface modules (Arneth et al., 2010a) is surprising.

Thus, with the current representations of the surface and surface exchange processes in these models being poor (i.e. at the wrong level of complexity), incomplete (i.e. missing key feedbacks) and/or over-calibrated, our understanding of LULCC-climate interactions is incomplete. Betweenmodel differences in how LULCC is represented in the land surface component of ESMs have been shown to account for more than two-thirds of the regional climate response to LULCC, even though the models concerned addressed biophysical processes only (Boisier et al., 2012; de NobletDucoudre et al., 2012; Pitman et al., 2009). Moreover, in the absence of specific representation of land management, for global-scale analyses of how LULCC affects ecosystem biogeochemical and biophysical processes, the natural grassland ecosystem class in dynamic global vegetation models (DGVMs) is typically assumed to represent agricultural land. This assumption ignores the major differences that exist in phenology, carbohydrate allocation, yields, ecosystem water balance and habitat diversity in crops or pastures compared with natural ecosystems (Schröter et al., 2005; Arneth et al., 2010b). Similarly, managed forests are often assumed to have the same structure and function as natural vegetation.

Observations of current land cover demonstrate the dominance of mosaic landscapes (Letourneau et al., 2012; Van Asselen and Verburg, 2012; see Fig. 3), but many land system models utilised within climate models only account for landscape heterogeneity by considering the fraction(s) of each grid cell that is covered by trees, grasses, crops, bare soil, open water etc. and solving the surface exchange for each surface fraction separately (known as "tiling"). While demonstrably better than applying a single, dominant land cover category for a particular area, tiling does not incorporate the transition regions from one surface type to another or properly represent surfaces where mixing is fundamental to the operation of the surface in its entirety (e.g. savannah, suburban, crop land with wind breaks) (see Mahrt, 1996, for discussions). The sensitivity of mosaic landscapes to change is therefore largely unknown, while at the same time mosaic landscapes are often most sensitive to LULCC given their frequent occurrence near frontiers of land change (Messerli et al., 2009; Rindfuss et al., 2003; Verburg et al., 2013).

As a consequence, linking process-based models of LULCC and the Earth system is indispensable. The realism with which land cover and the relevant biophysical and biogeochemical processes are represented in climate and Earth system must be improved. We are still at the stage of needing to undertake a thorough assessment of the role of LULCC on climate from a range of different perspectives (global, regional, adaptation, mitigation, biophysical, biochemical). This relates to historical simulations, as in some regions the largest rates of LULCC have already happened in the past. For other regions, rates of land conversion are still rather large, and will continue to be so, including both deforestation and afforestation. Both substantially affect global water use and runoff, as well as the exchanges of climate-relevant compounds beyond $\mathrm{CO} 2$ (i.e. $\mathrm{N}_{2} \mathrm{O}, \mathrm{CH}_{4}, \mathrm{NO}_{\mathrm{x}}$ ). A true understanding of the role of humans in the climate system must include an in-depth analysis of the LULCC-climate interplay across space- and timescales. This is fundamental in supporting the development of effective land-based mitigation options, as well as appropriate adaptation measures (Pielke et al., 2011).

\subsection{Climate change influences on LULCC}

Climate change can influence LULCC through both direct and indirect effects (see Fig. 2). Direct effects include the regional effects of climate on the suitability of particular locations for different types of land use, e.g. crop types or forest management. A number of climate-related variables can be important drivers of LULCC, including patterns of temperature and precipitation, and also wind damage, susceptibility 


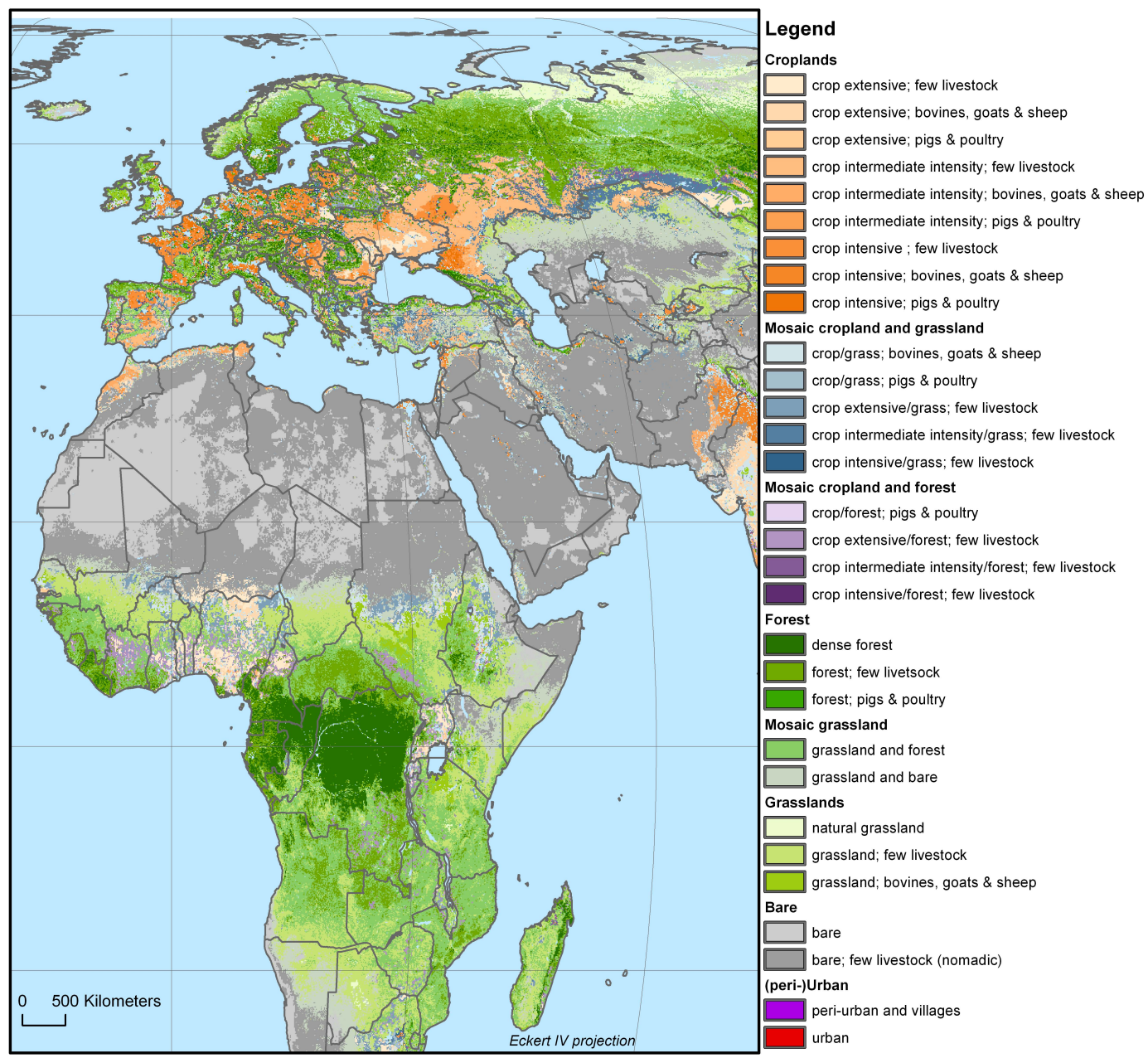

Fig. 2. Global land use systems (adapted from Van Asselen and Verburg, 2012).

to fire, and the frequency and magnitude of extreme events, including regional correlations in these events. Variables such as water availability, soil degradation, and disturbances from plant pests and diseases can all be climate-related and influence land use decisions. In addition, sea level rise driven by climate change can affect land use through not only the loss of land to inundation but also through river flooding effects on crop productivity and constraints on urban development (Jongman et al., 2012; Verburg et al., 2012).

The indirect effects of climate change on land use are mediated through socio-economic change: for example, through climate change policy. Mitigation policies may include largescale development of bioenergy and/or carbon sequestration (Mackey et al., 2013), which could have major implications for land use regionally and even globally through indirect land use change (iLUC; LULCC in a given region that arises from drivers elsewhere, e.g. the implementation of policy). Climate change may also contribute to migration or conflict, which in turn can affect regional land use. Indirect effects can also occur beyond the region of direct climate influence through impacts on prices and international trade, making regional climate impacts a potentially global issue (Hertel et al., 2010). Adaptation to climate change includes technological and institutional responses, or changes in crop choices and management based on the differential responses of crops to both $\mathrm{CO}_{2}$ and climate change (Lobell et al., 2008). Adaptation responses may in fact turn out to be more important influences on regional land use than the direct effect of climate change. A high priority for future research is to better understand which regions may be most sensitive to the various climate change impacts on land use, and whether these consequences are likely to be mainly the result of direct or indirect effects. 


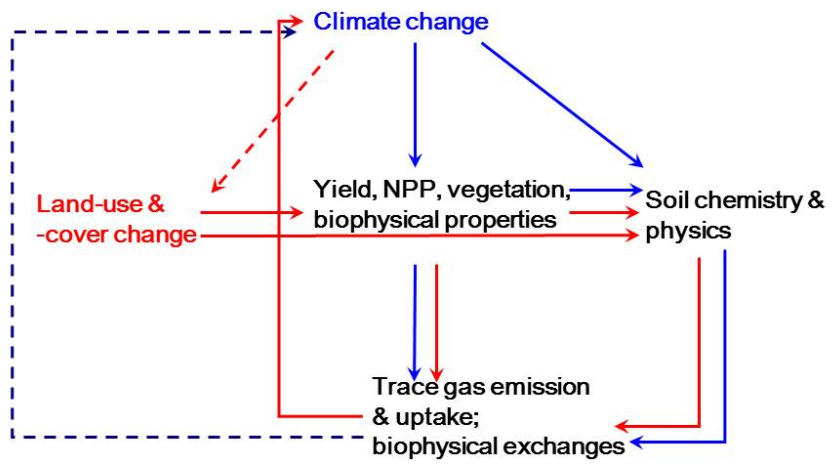

Fig. 3. Conceptual interactions of LULCC-climate impacts and feedbacks. Solid lines: impacts; dashed lines: feedbacks. Blue: LULCC-climate interactions. Climate change affects ecosystem net primary productivity (NPP) and other ecosystem properties (soil and vegetation), which affects trace gas emissions of greenhouse gases and land surface biophysical exchanges that are relevant to climate. These processes feedback to the original climate change (positively or negatively). Red: climate-change-LULCC interactions. LULCC has to be considered as an additional driver in the system that also affects ecosystem productivity and other ecosystem properties (soil and vegetation). The associated trace gas emissions of GHGs and land surface biophysical exchanges impact on climate change. The magnitude of a feedback from climate change back to LULCC is unknown.

\section{Advancing land system modelling at large scales}

\subsection{Improving models of the global land system by better representing human behaviour and decision-making processes}

Global-scale research on Earth system functioning is dominated by efforts to better represent the physical and biogeochemical processes in the climate, ocean and hydrological systems, while the contribution of social-science knowledge to major environmental change assessments is limited (Moran, 2010; Hulme, 2011). Although global environmental change is driven primarily by human activities, the representation of human decision-making global-scale models is highly simplistic compared with the depth of representation of physical processes (Rotmans and Asselt, 1996; Tallis and Kareiva, 2006; Rounsevell and Arneth, 2011). Earth system models and macro-economic models either assume human activities as an external driver or represent human behaviour by uniform simplistic (profit-optimising) assumptions that lack representation of the huge spatial and temporal diversity and interaction of human behaviour and decision processes (Meijl et al., 2006; Lotze-Campen et al., 2008; Britz and Hertel, 2011). Simplification of human decision making may lead to a lack of confidence in assessment results, hamper the ability to assess how people respond to environmental change as a system feedback, and limit the possibilities of using these models in the design and evaluation of possible alternative Earth system governance structures. A more thorough representation of human behaviour and decision making in Earth system models is clearly required (Lambin et al., 2006; Costanza et al., 2007; Liverman and Cuesta, 2008; Reenberg, 2009; Hulme, 2011; Rounsevell and Arneth, 2011).

Variation among individual actors - including class, ethnicity, gender and power, as well as between regions with different cultural-historical backgrounds and governance regimes - makes it necessary to better understand regional differences and design models that incorporate regional characteristics (Pahl-Wostl, 2002; Wilbanks, 2002; Evans et al., 2003; Rothman et al., 2009). The importance of local context has been the subject of much social research on the underlying drivers of LULCC with a focus on small-scale case studies rather than contributing to global-scale assessment tools (Turner II et al., 1990). More recently, new approaches have been developed to better represent variation in human behaviour and decision making in LULCC models at local to regional scales, e.g. through ABMs (Jakeman and Letcher, 2003; Verburg, 2006; Pahl-Wostl et al., 2007; Parker et al., 2008; Piorr et al., 2009; Hersperger et al., 2010). ABMs represent individual decision making accounting for variation among and interactions between heterogeneous actors across different levels. They have been used for modelling LULCC in a wide variety of settings (Matthews et al., 2007; Brown et al., 2008; Evans and Kelley, 2008; Acosta-Michlik and Rounsevell, 2009; Valbuena et al., 2010b). Agent-based modelling is typically the domain of interdisciplinary science: while the behavioural sciences help to define decisionmaking structures, these interact with the geography of the physical environment (Janssen, 2003; Brown and Robinson, 2006; Young et al., 2006; Bithell et al., 2008; Collins et al., 2011).

Whilst assumptions about profit maximisation of individual agents are a component of many ABMs, a wider range of factors influence land use decision making. In practice, ABMs are quite diverse. Some use profit maximisation, some utility maximisation, some non-economic decision processes. Economic factors hence enter more likely through the concept of utility maximisation (and sometimes risk aversion) and are implemented alongside of non-monetary behavioural factors. A number of studies have shown that a considerable part of the variance is not solely accounted for by profit-maximising models (e.g. Filatova et al., 2009), which leaves considerable room for improving models to deal with the non-economic components of land use decision making. Rounsevell et al. (2003) reported statistics for a profitmaximising model as representing between 15 and $58 \%$ of the variance within observed land use data depending on the particular land use in question. Berger (2001) demonstrated that imitation effects in terms of network/neighbour technology adoptions are required to completely explain lags in adoption of irrigation technologies. 
Even if constrained profit maximisation is the appropriate model, assumptions of full rationality simply might not work. For example, Filatova et al. (2009) demonstrate the failings of the representative agent assumption. Moreover, profit maximisation often fails in environments where risk and resource constraints (e.g. labour) are key, and where market integration is low (i.e. subsistence agricultural contexts). Studies on land use in residential (e.g. Nassauer et al., 2009; Hunter and Brown, 2012) and agricultural landscapes (Isham, 2002; Walters et al., 2005) provide ample evidence of spatial and social interaction effects on the way land is managed. Taken together, these studies demonstrate that a considerable part of the variance is not accounted for in profitmaximising models, which leaves considerable room for improving models to deal with the non-economic components of land use decision making.

ABMs have been used to analyse alternative development strategies and integrate social-science knowledge into operational simulation models at the regional scale (Robinson and Brown, 2009; Rounsevell et al., 2012). Although recent efforts have been made to include some of the diversity in socio-economic conditions in global-scale economic models (Melnikov et al., 2012), the representation of land use decision making in global-scale models does not yet take sufficient stock of the progress made in regional-scale ABMs. Understanding the role of the variation in humanenvironment interactions across scales is needed to advance the capabilities of integrated global assessments (Verburg et al., 2011). There are clearly alternatives to ABMs in achieving this, such as system dynamics models and computational general equilibrium (CGE) models (e.g. Forrester, 1971; Conrad, 2003; see also Sect. 3.3), but in our view both suffer from the same aggregation effects, which limit representation of heterogeneity and interactions. The distinction between ABMs and micro-simulation is less clear-cut, with both approaches focusing on individual entities. Micro-simulation models can be useful in dealing with some of what is done in agent-based modelling. However, micro-simulation models for LULCC are predominantly applied in urban environments (e.g. Huang et al., 2013), which is less appropriate to global-scale modelling. ABMs can also be distinguished from micro-simulation models by their emphasis on, and more elaborate options for, decision-making strategies of the individual units (agents). The preponderance of available LULCC modelling methods implies also the need to agree on standardised modelling approaches through common frameworks. An example of such a framework for ABMs known as the ODD (Overview, Design concepts and Details) has been beneficial in model development and sharing (Grimm et al., 2006; NRC, 2013).

\subsection{Methods for upscaling land system models to regional and global scale levels}

The simulation of local- to regional-scale LULCC has informed land use planning and environmental management (Verburg et al., 2004; Matthews et al., 2007; Schaldach and Priess, 2008) with different modelling techniques adapted to specific research questions and regional contexts. Validation of these models shows a wide variation in performance, depending on the complexity of the specific case, quality of input data, and the depth of the legend and scale of analysis (Castella and Verburg, 2007; Pontius et al., 2008). A broad categorisation of regional-scale models can be made on the basis of the focus of the simulation unit. A large group of models use spatially referenced land units that are usually pixels in a raster format. Models simulate changes in the land cover states of these pixels. The decision making of land managers is simplified by the specification of rules that govern the transitions in the state of these pixels as a function of the physical and socio-economic location conditions or the state of the neighbouring pixels. In ABMs, individual decision makers (or groups of decision makers) are the basic units of simulation, and thus the decision-making process is more explicitly simulated for the land parcels managed by these agents. In its most basic form, each agent is linked to a single pixel of land, which resembles pixel-based models. More advanced $\mathrm{ABMs}$ represent different types of agents and give specific attention to interactions between agents (at different levels) and include feedbacks between agent decision making and the environment (Brown et al., 2005; Verburg, 2006; Valbuena et al., 2010a).

Pixel-based models are often simplified to account for the limited availability of data as well as criteria for decision making at the global level. Decision rules used in models at the local or regional level often do not apply to the larger geographic extent and spatial resolution due to scaling issues (Verburg and Chen, 2000; Veldkamp et al., 2001), indicating the need for model respecification. A lack of coherent and suitably resolved socio-economic data at the global scale, compared to the relatively better availability of physical data, risks physical processes being specified in detail with the representation of decision-making processes being overly simplified (Schaldach et al., 2011; Letourneau et al., 2012). The problem needs to be approached at the appropriate scale level; perhaps at the global scale the issue is to look at the effects of decision making rather than the processes of decision making per se. Moreover, pixel-based approaches often have difficulty in representing higher-level processes that affect land use, such as international trade. To overcome this problem, multi-scale and multi-model approaches have been used in which the spatial LULCC models are used to downscale world-region-level land use allocations made by general or partial equilibrium models (Rounsevell et al., 2006; Verburg et al., 2008). 
Upscaling ABMs to the global level is hampered by the availability of sufficient data and knowledge of agent attributes for model specification and calibration (Rounsevell et al., 2012). Whilst an advantage of ABM is the representation of variations in decision making and interactions among actors and between actors and their environment, the scaling of fully parameterised models is restricted by data availability (Robinson et al., 2007). There are some examples of "massive" ABMs, for instance the Epicast model (Germann et al., 2006). This synthetic population model of America includes 360 million agents and was designed to model avian flu spread. An Australian version with 22 million agents has been used to model the spread of dengue fever under climate change (Newth and Gunasekara, 2010). These models illustrate the point that discrete ABMs of populations exhibit emergent properties that are not seen in aggregated models and which do not depend directly on the agent properties.

From a practical perspective, aggregation of the variation in agent decision making is inevitable (Smajgl et al., 2011). Two pathways of aggregation can be distinguished (Rounsevell et al., 2012): (1) representation of all individual agents globally and classification of these agents according to a limited number of clearly defined decision-making strategies following a typology, and (2) aggregation of individual agents into generic agents that represent more generalised decision-making processes, e.g. at the community level. Typologies that group agents with similar LULCC behaviour are common in ABMs, with agents being classified based on survey and census data (Valbuena et al., 2008; Boone et al., 2011; Smajgl et al., 2011; Guillem et al., 2012), as indicated, for example, in Fig. 4. Rounsevell et al. (2012) proposed the use of "human functional types" to classify agents, as an analogy to the vegetation typologies ("plant functional types") used in global vegetation models. The way in which such typologies are empirically derived, as well as the empirical parameterisation of such models from globally available information, remains a major challenge, although some attempts have been made to collect data that might be used for this purpose, e.g. the international household survey network and the CCAFS baseline surveys (www. ihsn.org; ccafs.cgiar.org/resources/baseline-surveys). Moreover, the connection of individual agents and the land resources they manage is difficult to establish (Rindfuss et al., 2003). These challenges may be difficult to overcome, but not impossible, and as with any model are likely to involve simplification. Simplification is, however, better than ignoring agent heterogeneity all together.

Although aggregate agent types do not represent realworld entities, they can represent emergent decision making at the level of communities or landscapes. LULCC case studies provide insight into underlying drivers that may be used to parameterise models (Lambin and Geist, 2003; Rudel, 2008). Aggregate representations also connect more easily to the observed spatial patterns of LULCC in available global data sets that result from such aggregate decision-making
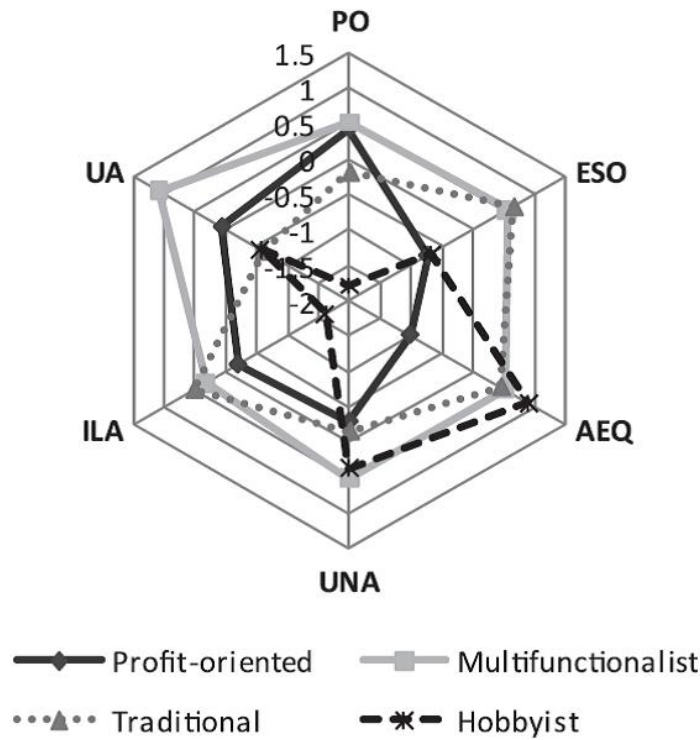

Fig. 4. An example agent typology derived from social survey indicating the different attitudes between types toward profit, social status and the environment. Abbreviations indicate profit orientation (PO), environmental and social orientation (ESO), awareness of environmental quality for birds (AEQ), understanding the needs of the agri-environment scheme (UNA), importance of landscape appearance (ILA) and uncertainty about the agri-environment scheme (UA) (after Guillem et al., 2012).

processes. Two ways of parameterising the decision-making processes of aggregate agents can be distinguished. The first uses detailed ABMs of individual decision making to understand how aggregate decision making emerges from the interactions between individual agents. The second approach derives aggregate decision making from meta-analysis of worldwide case studies. Both approaches require methodological advances before they can be implemented in globalscale models, and in either case, decision-making criteria still need to be specified. Most global models use strictly economic rationale to determine decision making, even though economic criteria are not always good proxies for how people behave (Meyfroidt, 2013), particularly in more subsistenceoriented settings. Decision variability might yield differences in the ultimate land use choices that agents make in equilibrium, compared to profit-oriented models, but even if the equilibrium outcome is the same, it is almost certain to have an influence on the transient dynamics of land use change (e.g. Evans et al., 2011). There are always winners and losers arising from LULCC, which has implications for the types of change, the ecological impacts and feedbacks to human wellbeing.

An alternative to using a typology or aggregate agent types is to model each agent individually. While the representation of all individual agents is computationally intensive, such simulations are now feasible (Lysenko and D'Souza, 2008). Figure 5 provides an example of how this can be done at the 


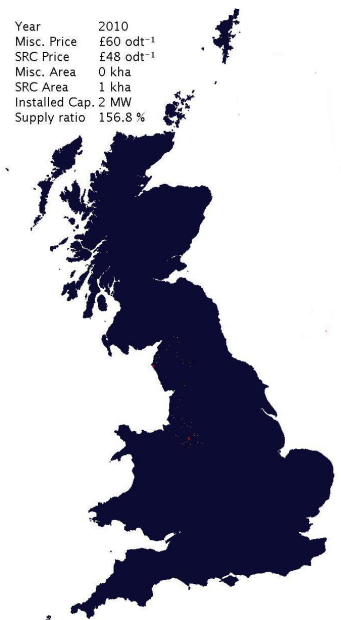

Energy crop area

$<5 \%$

5 to $10 \%$

10 to $15 \%$

15 to $20 \%$

20 to $25 \%$

25 to $30 \%$

30 to $35 \%$

35 to $40 \%$

40 to $45 \%$

45 to $50 \%$

$>50 \%$

Power Plant

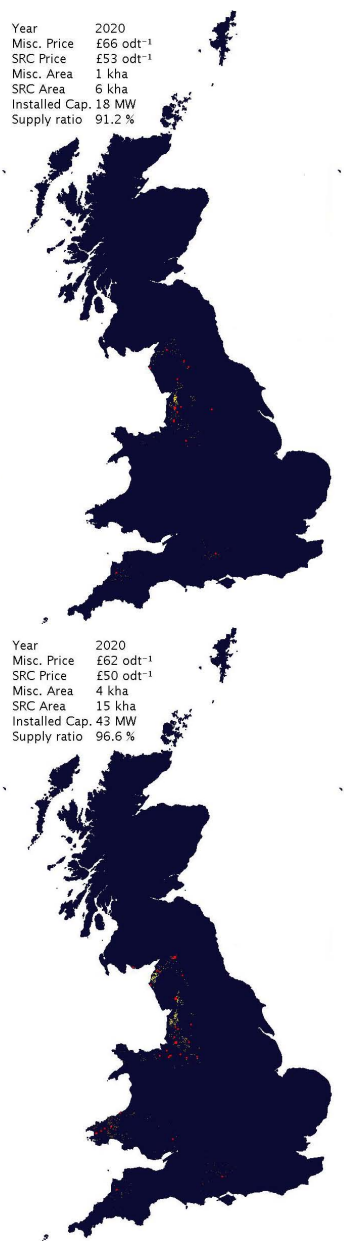

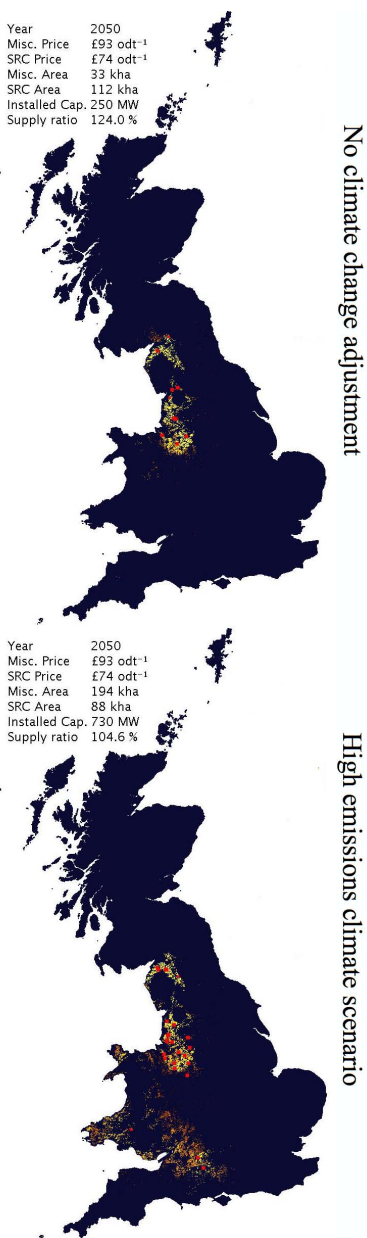

Fig. 5. Simulated future adoption of the energy crops Miscanthus (Misc) and short-rotation coppicing (SRC) in the UK with and without climate change from 2010 to 2050.

national level for the simulated adoption of energy crops by farmers in the UK (Alexander and Moran, 2013). The ABM used in these simulations models the interactions between the heterogeneous farmers supplying energy crops and the energy plant constructors demanding these crops (Alexander and Moran, 2013). The patterns of energy crop expansion demonstrate the influence of farmer-agent interactions that control the rates of adoption in a spatial diffusion process. Productivity gains of Miscanthus under the climate change scenario produce a switch away from short-rotation coppicing and supports an increase in the total energy crop market size.

\subsection{Bridging the gap between general equilibrium models and individual-based models of the land system}

Global-scale assessments of LULCC frequently use computable general equilibrium (CGE) models that seek to describe production, consumption and exchange of goods and services in an entire economy. CGE models have been widely applied to quantify the macro-economic and sectoral impacts of many types of environmental policies including climate policies (Conrad, 2003). CGE models are also used increasingly to assess the economic impacts of climate change on agriculture and other sectors (e.g. Eboli et al., 2010), including the impacts on land use (Britz and Hertel, 2011; Hertel et al., 2010). CGE models combine empirical data on flows of goods and services between sectors and households with specifications of demand, supply and markets grounded in micro-economic theory. "General equilibrium" refers to the set of (relative) prices at which supply meets demand in every market. "Computable" refers to the determination of this solution by one of several possible computational methods. Typically, these models are "calibrated" so that the initial equilibrium corresponds to the observed state of the economy in a base year. In a policy (or other) simulation, the resulting new equilibrium is compared to the initial state. Such comparative analysis provides insight into the marginal impacts of particular policies on the (re)distribution 
of resources within the economy, and by extension on the merits of one policy over another.

CGE models developed to analyse the impacts of climate policies are distinguished primarily by their representation of greenhouse gas emissions from economic activities. Early studies were focused on policies to mitigate fossil $\mathrm{CO}_{2}$ emissions, but recent studies have also focused on the emissions associated with LULCC (e.g. Hertel et al., 2009a). There have also been attempts to model the impacts of climate change in various sectors, including agriculture and forestry (e.g. Calzadilla et al., 2011). This requires the development of models that have better representations of land resources and uses - an area of continuing methodological innovation. Land resources may be distinguished as a factor of production in CGE models, along with labour and capital. Many models concerned with land-based production distinguish a single type of land that is used by all sectors and for which the aggregate supply is either fixed or is a prescribed function of price. Some CGE models distinguish multiple types of land. The most prominent example of this is the GTAPAEZ and similar models that distinguish land in up to 18 different "agro-ecological zones" per model region (Hertel et al., 2009b). LULCC is then modelled as a simple function of the relative land rental rates for each use. Limited flexibility to reallocate land between different uses (especially in the short to medium run) is often modelled with nested constant elasticities of transformation: higher between more similar uses (e.g. different field crops) and lower between less similar uses (e.g. pasture versus crops) (Hertel et al., 2009b).

It is important to distinguish between the limitations of the current generation of large-scale CGE models of LULCC due to data, methodological and computational constraints and any limitations of the neoclassical theories of production, consumption and general equilibrium. The theory requires that agents maximise utility, but it does not require that all agents be identical, nor that consumption and production decisions be separable. There are now many examples of computational models with heterogeneous households (e.g. Rausch et al., 2011). Löfgren and Robinson (1999) embed a model of farm household behaviour within a CGE framework in which production and consumption decisions are non-separable. Allowing for various types of spatial interactions in a CGE framework is much more challenging, but not impossible (e.g. Bröcker, 1998).

The potential exists to integrate CGE models with ABMs and thus exploit the advantages offered by the two approaches (for the farm-level see, for example, Schreinemachers et al., 2010). The most salient feature of ABMs from the perspective of this integration is their ability to model decentralised market decisions, while taking into account agent and spatial heterogeneity and interactions (Nolan et al., 2009; Parker et al., 2003). Many agricultural ABMs represent decision processes using traditional mathematical programming approaches taken from agricultural economics, jointly allocating farm-level resources and capital to determine land allocation and economically optimal outputs. Such models can incorporate forward-looking behaviour and fixed costs, resulting in more realistic land use transitions without the imposition of artificial constraints. They can also incorporate subsistence constraints and nonmarket cultural preferences, moving away from a pure profit or utility optimisation approach. ABMs can also allocate land sales and rental markets endogenously through land markets, and in doing so estimate spatially heterogeneous land rental rates (Berger, 2001; Happe et al., 2006; Parker and Filatova, 2008). Thus, ABMs can overcome some of the limitations of CGE models by modelling a wider range of land uses, accounting for spatially heterogeneous land suitability - which potentially varies with climate change - and endogenising land use transitions, diffusion of innovation, and land rents. However, options for coupling of CGE and ABMs have not yet been formally explored. We argue here also for the exploration of novel approaches that start with a clean slate as a complementary approach that merits consideration in parallel with the continued development of existing methods. This would provide much-needed diversity in method development from which the next generation of LULCC modelling approaches are more likely to benefit (NRC, 2013).

\subsection{Agent learning and evolution}

By representing the individual actors who make land-change decisions, ABMs can represent these decision processes in some detail. This includes limitations in agent cognition, access to information or social interactions that might produce non-optimal individual-level decisions (i.e. referred to as bounded rationality). An important component of human decision making is the ability to learn and adapt in dynamic social or environmental change contexts. The learning and adaptation of individual agents can evolve within the system of which the agents are a part (Parker et al., 2003) to create feedbacks that can lead to complex dynamics such as threshold effects, multiple equilibria and path dependency. Agent learning and evolution and how these contribute to decision making remains a fundamental problem in ABMs. It has been summarised as the problem of parameterising inductive reasoning. While social psychology has not yet produced an uncontested theory of inductive reasoning (Perez, 2006), learning and evolution can take on relatively simple or complex forms at the agent level, with the more complex forms requiring algorithmic, as opposed to closed-form mathematical, representation. A simple form of learning is to include some memory of past performance as a consequence of a decision or decisions, and making future decisions in a way that mimic or incorporate the decision approaches that produced the best outcomes. Similarly, information about the performance of decisions carried out by other agents connected through spatial contiguity or social networks could be queried by an agent and those decisions mimicked or incorporated in some way (Polhill et al., 2001). 
More complex representations of adaptation and learning have been represented using evolutionary algorithms (Holland, 1975), which include (a) some sort of mechanism for modifying the parameters or structure of a decision rule and (b) a fitness measure that scores the performance of the modified versions. In land use models, these evolutionary or genetic algorithms have been used to select and weight criteria that agents use in a multi-criteria evaluation of alternatives (Manson, 2006) and, more simply, to allow agents to decide on the value of a single parameter based on the decision-making performance of various alternative values (Magliocca et al., 2011). Using evolutionary algorithms to represent agent cognition requires more computation, because agents need to test multiple alternative choices, as well as more data, because those choices need to be compared with a measurable outcome variable. They have the advantages, however, of (a) facilitating representation of decision processes (not just decisions) that evolve and adapt over time on the basis of feedback from the outcomes, and (b) permitting specific representation of various types of bounds on rationality (An, 2012; Manson, 2006; Meyfroidt, 2013). Other approaches are available to model adaptive learning, including Bayesian belief networks and artificial intelligence (Meyfroidt, 2013). However, so far these approaches have not been applied to the LULCC decision-making domain.

Participatory or co-modelling approaches have taken an important place alongside other sources of empirical information for ABMs (Robinson et al., 2007; Jones et al., 2009). Unfortunately, there seems little prospect of scaling such methods up to national or global scale levels. While there is substantial empirical evidence to suggest that the dominance of contingency in social decision making at small group scale can be replaced by emergent regularities at the large scale (Finnigan et al., 2012), at this stage we cannot describe the rules and typologies of these large-scale emergent social behaviours. Computational experiments offer a promising approach to identifying the implications of decision processes represented at the micro-scale for larger-scale dynamics at the level of agent groups, sectors or regions. Meanwhile, global-scale models need to be employed within scenarios to explore possible or likely future states.

\subsection{The role of institutions in land system models}

All models dealing with human uses of land and "natural capital" include assumptions, implicitly if not explicitly, about institutions in such forms as property rights, zoning ordinances, and regulations dealing with pollution and other matters involving actions of landowners that affect the wellbeing of others. Strategies are available to incorporate institutions into existing models or to build new models that deal with land use. One strategy emphasises comparative statics, in which land use models are run with alternative assumptions about institutional arrangements to explore how institutional differences affect the land use outcomes (Zellner et al., 2010; Bell et al., 2012). The same approach can be used to explore the ways in which institutional rules interact with individual level behaviours, in cases where rules are enforced imperfectly or where social norms (informal institutions) exert an influence on land use behaviours that interacts with formal institutions (e.g. Agrawal et al., 2013). The other strategy emphasises institutional dynamics and focuses on processes through which institutions relevant to land use form and change through time (Zellner et al., 2009). This approach assess the criteria used within the decision processes of the institutional decision makers (e.g. environmental quality or economic performance) directly, e.g. through game theory, to evaluate how institutions change in response as their perceptions of performance change over time.

Using the comparative statics strategy, it is possible to explore any number of institutional differences. For example, rules can be introduced to provide those who use land with incentives for management of ecosystem services that are ordinarily ignored by private owners, and regulations designed to protect non-owners from the impacts of various types of land use. A good example of the use of incentives is the establishment of "current-use programmes" that grant property tax relief to landowners who leave land in a "natural" state or use land in a manner that protects habitats for wildlife, controls erosion and so forth. A recent development of interest in this realm features what are known as conservation easements in which landowners sell development rights to land trusts or donate these rights in return for some form of property tax relief. Key examples of regulation include measures designed to minimise air and water pollution associated with land use (e.g. runoff containing fertilisers or pesticides), to minimise deforestation through establishment of protected areas or harvest quotas, or to avoid forms of development offensive to neighbours (e.g. loud or unsightly industrial activities). The classic challenge is to strike a balance between the rights of landowners and the rights of others in such a way as to enhance social welfare without triggering what are known as "regulatory takings".

Turning to institutional dynamics, the focus shifts to the emergence of institutions and to their evolution through time. We can differentiate three processes through which institutions form and change: (i) self-generation or the emergence of rules that take the form of informal, but commonly understood social conventions, (ii) negotiation or the conscious adoption of rights and rules by actors (e.g. legislators, diplomatic representatives) authorised to act on behalf of society, and (iii) imposition or the selection and enforcement of rights and rules by a dominant actor in society. There is an important distinction between the ideal and the actual in this realm (rules in use can and often do differ substantially from rules on paper) as well as the fact that institutional arrangements change continually after they are put in place. Furthermore, institutional arrangements can interact among these three types (Agrawal et al., 2013) or between institutions of a given type (Zellner et al., 2009). An example of the latter 
was illustrated by Tiebout (1956), who showed that municipalities within a region provide services to mobile populations for which they compete through the choices they make about the services they provide.

While many of these processes have been represented explicitly in the land use models cited above, an alternative option would be to model institutional turning points or transitions in which major changes in prevailing institutions are introduced through the passage of legislation (e.g. the Clean Air Act Amendments of 1990 in the US mandating major reductions in emissions of sulfur dioxide and nitrogen oxides) or the negotiation of international agreements (e.g. the adoption of the 1987 Montreal Protocol, leading to dramatic reductions in the production and consumption of ozonedepleting substances). Econometric analyses can be used to reveal the quantitative effects of these turning points after the fact, as has been illustrated for the use of protected areas in the developing world (Andam et al., 2008) and the effects of the Conservation Reserve Program in the US (Lubowski et al., 2008). Both of the above simulation strategies are likely to be useful in efforts to estimate the effects of similar policies in future scenarios. The comparative statics strategy may prove helpful in thinking through the probable consequences of introducing alternative tax schemes, zoning ordinances (Zellner et al., 2010) or regulatory policies and enforcement (Bell et al. 2012). Building institutional dynamics into land use models is apt to prove more challenging, but such efforts may turn out to be helpful in exploring how interactions among biophysical, economic and institutional forces determine the trajectories of systems in which human drivers have become dominant.

\subsection{Representing technology innovation and adoption in land system models}

Technological innovation is a broad concept that can encompass many different processes, techniques or devices. In partial and general equilibrium models, production functions govern the behaviour of individual industries within large global regions, and these functions include land as one type of input. Changes in productivity can in principle result from many different sources: increased inputs (e.g. labour), changes in management (e.g. multi-cropping, changes in timing of planting/harvest), changes in management involving new inputs such as fertilisers or irrigation, new technologies such as better machinery or improved crop varieties, or changes to biophysical land productivity due to improved soils or climate change. The distinction between exogenous and endogenous productivity changes depends on the model structure. Exogenous assumptions about the productivity of land (or, in some cases, total factor productivity) will generally incorporate all sources of productivity change not otherwise explicitly represented. For example, in a CGE model that distinguishes a separate fertiliser industry, agricultural industries can endogenously shift toward increased fertiliser inputs, which will have the net effect of increasing the output produced for a given amount of land inputs. However if a fertiliser industry is not explicit, then shifts in output due to increased fertiliser use can be represented only implicitly through assumed exogenous changes in productivity. Thus technological change is represented differently depending on model structure.

\subsection{The importance of connectivity through networks}

The Earth system is increasingly interconnected through trade flows (imports/exports), human movement (migration) and information exchange (telecommunications) (Lambin and Meyfroidt, 2011; Meyfroidt et al., 2010; Seto et al., 2012). These teleconnections have important implications for LULCC globally since they affect consumption and production patterns for land-based goods and services and the means to inform different land use decisions. These global flows both influence and are affected by land use and include embodied materials in products such as water in food (Dalin et al., 2012; Porkka et al., 2012).

Economic drivers have dynamics that are determined in some important ways by the topology of trade and financial networks. Food production in modern agricultural systems, for example, is very dependent on energy for fertiliser production, farm operations, transport and processing. Oil and gas, which supply much of this energy, are internationally traded between a few producers and many importing countries. Network analyses of world trade and the monetary system that enables it through markets and credit involve extremely complicated networks (e.g. Brede and Boschetti, 2009; Fagiolo et al., 2009; Schweitzer et al., 2009). Trade networks may be vulnerable to dynamic and/or topological instability. In dynamic instability, small shocks to food and primary energy availability propagate through the network and grow in amplitude. In topological instability, flows are vulnerable to the failure of critical links or nodes: for example, the interdiction by Ukraine of natural gas supplies from Russia to western Europe. Network instability becomes interdependent when growing perturbations in flows (dynamic instability) overload links in the network causing them to fail (topological instability).

Together these features mean that even without major economic shocks, the price, availability and supply of food and energy is intrinsically volatile. For example, the FAO food price index rose steeply by over $50 \%$ in 2008 following growth in oil prices, then fell in 2009-2010 before hitting new highs in 2011-2012 (FAO, 2012). We are now seeing unprecedented price volatility superimposed on a trend of price increases. It remains to be seen whether this will continue, but the structure of the underlying trade and supply networks suggests that this kind of behaviour should not be surprising. Ex ante analyses of food and other commodity price spikes find deterministic explanations of these phenomena (Bobenrieth and Wright, 2009), but network analysis 
suggests that events of this kind should be endemic given the structure of trade flows in a globalised world. Similar analyses have been performed for primary energy and for the financial system, which can be viewed as the information flow which enables physical trade flow (May et al., 2008; Schweitzer et al., 2009). Hence key economic drivers of land use at the local scale, i.e. commodity prices and availability, are fundamentally stochastic.

The level of detail in the structure of economic flows is not captured in global models. CGE models such as GTAP (Hertel, 1997) or GTAP variants such as GTEM (Pant, 2002) generally restrict themselves to dealing with a few (10-20) geographical regions, although they may have detailed representation of many economic sectors $(\sim 50$ or more) within these regions. As a result, they are explicit in calculating networks of trade flows in each economic sector between regions. However, this approach precludes representation of non-linear network behaviour. CGE modelling of physical flows has been combined with physical and biological constraints in IAMs such as IMAGE (Bouwman et al., 1996) or IGSM (Sokolov et al., 2005). When these models include explicit descriptions of LULCC, the CGE framework is in principle able to specify some of the economic drivers such as prices and terms of trade. This is currently the state of the art, but is subject not only to the shortcomings noted above but also to the other well-known problems of DSGE/CGE economic modelling, even when that is augmented by physical processes in IAMs.

Social drivers are strongly influenced by social networks at small scales, and there are numerous examples of social network analyses (e.g. McAllister et al., 2011). At medium scale levels (regional to national), local land use responses to economic drivers are moderated through social networks often characterised by early adaptors, followers and resisters that can be made manifest in a social network topology (e.g. Barabasi, 2002). At larger scale levels, political influences described as networked processes can have major effects on land use. For example, the move to economic autarky in the developed world between the two world wars was in stark contrast to the evolution towards global trade up to 1914 and the rapid expansion of globalisation after WW2 (Collier and Dollar, 2002). Pre-WW2, land use in European colonies was strongly influenced by the commodity preferences of the homeland, while post-WW2, the institutions set up at Bretton Woods actively facilitated trade with bilateral benefits (at least in principle). We are now seeing the continued working-out of this process with the legal acquisition of land in places such as sub-Saharan Africa, Australia and New Zealand to secure food supplies for centres of rapid population growth in Asia or by stateless multinational corporations (see Wouterse et al., 2011). Network modelling is a natural tool for capturing some of these processes, but thus far little progress has been made other than at a conceptual level, especially in representing institutional processes within government and the private sector.

\subsection{The way forward for data assimilation and synthesis}

Global understanding of LULCC processes requires synthesis of observations and models across local and regional scales. While remote sensing and global climate modelling have revolutionised our ability to observe and model the global patterns and dynamics of biophysical systems, the human systems that cause LULCC are not directly observable from space, nor can they be modelled successfully at global scales without understanding how they function locally and regionally. Thus, the assimilation and synthesis of multidisciplinary case study observations and models made at local and regional scales is necessary to represent land use decision making in land system models (Turner II et al., 2007).

Progress has been made in generating global knowledge from local and regional case studies by acquiring and combining sets of published studies using a variety of methods that have become increasingly quantitative and powerful (e.g. Rudel, 2008; Vliet et al., 2012). Yet these studies still suffer from serious biases in the selection of study sites ("interesting locales", logistical concerns) and in the availability of case study results (language, publication access, social networks etc.). There are also major logistical and technical challenges to overcome when collecting and integrating large sets of studies for meta-analysis to produce quantitative global estimates (Geist and Lambin, 2006; Rudel, 2008; Ellis et al., 2009; Vliet et al., 2012). Thus, the data and knowledge needed to upscale data-intensive models, such as ABMs, remains fragmented, presenting a significant barrier to the representation of human decision making in regional and/or global land system models. Appropriate case studies exist, but there is currently no means of connecting, assimilating, organising and synthesising the results of these studies. This reality is reflected in the paucity of LULCC models that attempt detailed representations of decision making above the local case study scale (e.g. Valbuena et al., 2010a).

Given the already large data demands of global climate and land system models, the additional requirements for parameterising model representations of decision-making processes are especially daunting given the unstructured and multidisciplinary nature of LULCC case study research. A way forward may be to use online facilities to share and synthesise case study findings across a network of LULCC researchers that improves access to global physical and socioeconomic data. In this respect, a number of socio-economic data portals are currently available or under development for LULCC applications and these seek to provide access points for required data. Portals include GEOSHARE (Hertel and Villoria, 2012; www.geoshareproject.org), NASA's socio-economic data centre (SEDAC), the University of Wisconsin's SAGE (www.sage.wisc.edu/), DataONE (www. dataone.org), the GLOBE project (http://globe.umbc.edu) and the Integrated Public Use Microdata Series (iPUMS; Minnesota Population Center, 2013). The most challenging element of creating and sharing repositories of LULCC 
knowledge is likely to be the need for sustained support for these efforts that is adequate in enabling their capabilities to grow beyond ad hoc efforts and experiments. Nevertheless, the creation and use of online collaboration infrastructures does tend to drive enhanced data sharing, harmonisation and use to answer broader questions.

\section{Conclusions}

The climate change debate centres on the question of human impact. From this perspective the chief model developments over the last decades seem to have disproportionally concentrated on reducing uncertainty and more detailed process modelling of the physical climate system with GCMs. Equal attention has not been paid to global models that investigate human-system processes, for instance through improved IAMs or globally applicable ABMs. The greatest uncertainty in future climate predictions lies in the range of possible emission trajectories, and not in the inherent unpredictability of the biophysical climate system given a predetermined forcing. Clearly, efforts to improve understanding of human drivers and responses require more attention. This sits in the "understanding" realm, but with clear impacts for steering future science and the "projection/prediction" issue. The hard part is that multiple representations of global LULCC coupled with the ESMs would be needed to address this.

In particular, the issue of LULCC as a climate driver has largely failed to gain traction to date because of (a) the intrinsic difference in the scales at which land use decisions are made and those usually implied when discussing climate and because (b) the current rudimentary treatment in ESMs of LULCC (and terrestrial processes more generally) provides little evidence to suggest that more detailed representations of LULCC would lead to increases in predictability, and/or large magnitude impacts, at climate-relevant scales. However, a primary goal of Earth system modelling should be to improve understanding of the interactions and feedbacks between human decision making and biophysical processes. The need for this is driven by urgent calls for effective global stewardship to be informed by such understanding (Chapin III et al., 2010). In this respect, a particularly important (and ambitious) aim is to use system understanding to enable transitions and transformations in social-ecological systems.

Our ability to anticipate future technological and social change is limited, and not necessarily within the scope of most modelling projects; hence the emphasis this paper has placed on representing technological change, innovation and social change (e.g. evolution of institutions and human behaviour) in models. Given the importance of network connectivity, innovations in social systems that affect knowledge sharing have profound potential to shift the social norms, institutions and governance systems that ultimately shape our future landscapes and climate (e.g. enabling global stewardship of material and energy flows). These interactions between institutions, human behaviour and system transformation become paramount if modellers are to contribute the knowledge needed to shape future systems.

There will always be room for simple models as well as very complex ones - their application domain and their strengths and weaknesses depend on the question to be addressed (Fulton et al., 2012). We do not know whether better representation of social processes in global models would make their predictive capacity better. Until such models do exist, it is not possible to undertake the model experiments and sensitivity analyses to support or refute the benefits of such an approach. Moreover, it is important to highlight here that modelling can have very different objectives. Models are sometimes used to make projections, and in these cases process-based models are not always the best way forward. But modelling can also be used to advance understanding of processes by constructing experiments that explore different representations of those processes. In reviewing and evaluating different modelling strategies we have highlighted readily accessible opportunities to improve existing modelling capabilities, and these steps would also contribute to the more intractable challenges identified. In particular, it is clear we can learn much from comparing consequences of quite different representations of the same processes in different models (e.g. representation of land change and climate change interactions in climate models versus land system models, or working with both ABM and CGE approaches). Existing models are helpful here as they provide a clear framework for being explicit about assumptions, developing and refining hypotheses and enabling useful analyses that resolve questions about climate and land interactions. In this way models are used to frame falsifiable hypotheses.

In pursuit of these aims it is clear that model intercomparison exercises and investigations into model equifinality do much to further our scientific understanding. There is rarely a single, unambiguous way to conceptualise and represent these system effects in models, and yet model results can be profoundly sensitive to that choice of representation.

The most challenging questions raised here set the scene for longer term research opportunities. The contingent nature of human behaviour severely limits the potential for testable, quantitative predictions in social-ecological systems. For this reason, it is helpful to identify both model purposes and evaluation methods that do not rely on quantitative prediction in order to be effective. It is very common to be drawn into discussions on what is missing from a model, and continue to embellish by adding process detail. Avenues for adding what is missing are boundless, and thus it is equally important to develop ways of prioritising and working with incomplete knowledge.

Given these challenges of unbounded search spaces and incomplete knowledge, quests to optimise or narrow in on certain answers can be inappropriate and misleading. It is helpful, however, to seek out situations where system 
representation (e.g. connectivity, non-linearities, cross-scale interactions, level of process detail) makes a significant difference to our interpretation. For example, alternative models may not even agree on the direction of a response to a prescribed perturbation, let alone the magnitude; for example, will water availability in an agricultural region be higher or lower in response to climate change (Chiew et al., 2011)? In this case, the key understanding for a decision maker might be that building in resilience to a range of possible eventualities is more prudent than optimising for an assumed, certain outcome.

Acknowledgements. The authors would like to thank the Global Land Project (www.globallandproject.org) and CSIRO for supporting this work. M. D. A. Rounsevell and PV would like to acknowledge the support of the European Commission-funded VOLANTE project (FP7-ENV-265104). A. Arneth acknowledges funding from the Formas Strong Research Environment "Land use today and tomorrow". M. D. A. Rounsevell, P. H. Verburg and A. Arneth acknowledge the support of the European Commissionfunded OPERAs project (Operationalising Ecosystem Research Applications, FP7-ENV-2012-308393-2) and the project LUC4C (Land use change: assessing the net climate forcing, and options for climate change mitigation and adaptation; grant no. 603542). P. H. Verburg acknowledges support of the European Commissionfunded GLOLAND project (Integrating human agency in global-scale land change models, ERC-StG-2012-311819).

Edited by: V. Lucarini

\section{References}

Acosta-Michlik, L. and Rounsevell, M. D. A.: An agent-based framework for assessing vulnerability futures, in: Chapter 9, Assessing Vulnerability to Global Environmental Change - making research useful for adaptation decision making and policy, edited by: Patt, A. G., Schroeter, D., Klein, R. J. T., and de la VegaLeinert, A. C., Earthscan, London, 147-171, 2009.

Agrawal, A., Brown, D. G., Rao, G., Riolo, R., Robinson, D. T., and Bommarito, M.: Interactions between Organizations and Networks in Common-Pool Resource Governance, Environ. Sci. Policy, 25, 138-146, 2013.

Alexander, P. and Moran, D.: Impact of perennial energy crops income variability on the crop selection of risk averse farmers, Energy Policy, 52, 587-596, 2013.

An, L.: Modeling human decisions in coupled human and natural systems: review of agent-based models, Ecol. Model., 229, 2536, 2012.

Andam, K. S., Ferraro, P. J., Pfaff, A., Sanchez-Azofeifa, G. A., and Robalino, J. A.: Measuring the effectiveness of protected area networks in reducing deforestation, P. Natl. Acad. Sci. USA, 105, 16089-16094, 2008.

Arneth, A., Harrison, S. P., Zaehle, S., Tsigaridis, K., Menon, S., Bartlein, P. J., Feichter, J., Korhola, A., Kulmala, M., O'Donnell, D., Schurgers, G., Sorvari, S., and Vesala, T.: Terrestrial biogeochemical feedbacks in the climate system, Nat. Geosci., 3, 525532, 2010a.
Arneth, A., Sitch, S., Bondeau, A., Butterbach-Bahl, K., Foster, P., Gedney, N., de Noblet-Ducoudré, N., Prentice, I. C., Sanderson, M., Thonicke, K., Wania, R., and Zaehle, S.: From biota to chemistry and climate: towards a comprehensive description of trace gas exchange between the biosphere and atmosphere, Biogeosciences, 7, 121-149, doi:10.5194/bg-7-121-2010, $2010 \mathrm{~b}$.

Arora, V. K. and Montenegro, A.: Small temperature benefits provided by realistic afforestation efforts, Nat. Geosci., 4, 514-518, 2011.

Barabasi, A.-L.: Linked, the new science of networks, Perseus Publishing, Cambridge, Mass., 280 pp., 2002.

Bell, A. R., Riolo, R. L., Doremus, J., Brown, D. G., Lyon, T. P., Vandermeer, J., and Agrawal, A.: Fragmenting forests: The double edge of effective forest monitoring, Environ. Sci. Policy, 16, 20-30, 2012.

Berger, T.: Agent-based spatial models applied to agriculture: A simulation tool for technology diffusion, resource use changes, and policy analysis, Agricult. Econ., 25, 245-260, 2001.

Betts, R. A.: Offset of the potential carbon sink from boreal forestation by decreases in surface albedo, Nature, 408, 187-190, 2000.

Bithell, M., Brasington, J., and Richards, K.: Discrete-element, individual-based and agent-based models: Tools for interdisciplinary enquiry in geography?, Geoforum, 39, 625-642, 2008.

Bobenrieth, E. S. and Wright, B. D.: The food price crisis of 2007/2008: Evidence and implications, University of Concepcion, Chile, and University of California, Berkeley joint meeting of intergovernmental group on oilseeds, oils and fats (30th session), intergovernmental group on grains (32nd session), Intergovernmental group on rice (43rd session) and symposium on Value chains for oilseeds, oils and fats, grains and rice: Status and outlook, 4-6 November 2009, Santiago, Chile, 2009.

Boisier, J.-P., De Noblet-Ducoudré, N., Pitman, A., Cruz, F. T., Delire, C., van den Hurk, B. J. J. M., Van der Molen, M. K., Müller, C., and Voldoire, A.: Attributing the impacts of Land-Cover Changes in temperate regions on surface temperature and heat fuxes to specifc causes. Results from the first LUCID set of simulations, J. Geophys. Res., 117, D12116, doi:10.1029/2011JD017106 2012.

Boone, R. B., Galvin, K. A., Burn Silver, S. B., Thornton, P. K., Ojima, D. S., and Jawson, J. R.: Using coupled simulation models to link pastoral decision making and ecosystem services, http: //www.ecologyandsociety.org/vol16/iss2/art6/, Ecol. Soc., 16, 6, 2011.

Bousquet, F. and Le Page, C.: Multi-agent simulations and ecosystem management: a review, Ecol. Model., 176, 313-332, 2004.

Bouwman, A. F., Kram, T., and Klein Goldewijk, K.: Integrated modelling of global environmental change, An overview of IMAGE 2.4, Netherlands Environmental Assessment Agency, Bilthoven, 1996.

Brede, M. and Boschetti, F.: Analyzing weighted networks: An approach via maximum flows, Lect. Not. Inst. Comput. Sci., 1, 1093-1104, 2009a.

Britz, W. and Hertel, T. W.: Impacts of EU biofuels directives on global markets and EU environmental quality: An integrated PE, global CGE analysis, Agr. Ecosyst. Environ., 142, 102-109, 2011.

Bröcker, J.: Operational spatial computable general equilibrium modeling, Ann. Reg. Sci., 32, 367-387, 1998. 
Brovkin, V., Sitch, S., von Bloh, W., Claussen, M., Bauer, E., and Cramer, W.: Role of land cover changes for atmospheric $\mathrm{CO}_{2}$ increase and climate change during the last 150 years, Global Change Biol., 10, 1253-1266, 2004.

Brovkin, V., Claussen, M., Drieschaert, E., Fichefet, T., Kicklighter, D. W., Loutre, M. F., Matthews, H. D., Ramankutty, N., Schaeffer, M., and Sokoloy, A.: Biogeophysical effects of historical land cover changes simulated by six Earth system models of intermediate complexity, Clim. Dynam., 26, 587-600, doi:10.1007/s00382-005-0092-6, 2006.

Brown, D. G. and Robinson, D. T.: Effects of heterogeneity in residential preferences on an agent-based model of urban sprawl, Ecol. Soc., 11, 46, 2006.

Brown, D. G., Riolo, R. L., Robinson, D., North, M., and Rand, W.: Spatial process and data models: Toward integration of agentbased models and GIS, J. Geogr. Syst., 7, 1-23, 2005.

Brown, D. G., Robinson, D. T., An, L., Nassauer, J. I., Zellner, M., Rand, W., Riolo, R., Page, S. E., and Low, B.: Exurbia from the bottom-up: Confronting empirical challenges to characterizing complex systems, GeoForum, 39, 805-818, 2008.

Brown, M. E. and Funk, C. C.: CLIMATE: Food Security Under Climate Change, Science, 319, 580-581, doi:10.1126/science.1154102, 2008.

Calzadilla, A., Rehdanz, K., and Tol, R. S. J.: Trade liberalization and climate change: A computable general equilibrium analysis of the impact on global agriculture, Water, 3, 526-550, 2011.

Castella, J. C. and Verburg, P. H.: Combination of process-oriented and pattern-oriented models of land use change in a mountain area of Vietnam, Ecol. Model., 202, 410-420, 2007.

Chapin III, F. S., Carpenter, S. R., Kofinas, G. P., Folke, C., Abel, N., Clark, W. C., Olsson, P., Stafford Smith, D. M., Walker, B., Young, O. R., Berkes, F., Biggs, R., Grove, J. M., Naylor, R. L., Pinkerton, E., Steffen, W., and Swanson, F.J.: Ecosystem stewardship: Sustainability strategies for a rapidly changing planet, Trends Ecol. Evol., 25, 241-249, 2010.

Chiew, F. H. S., Young, W. J., Cai, W., and Teng, J.: Current drought and future hydroclimate projections in southeast Australia and implications for water resources management, Stoch. Environ. Res. Risk A., 25, 601-612, 2011.

Collier, P. and Dollar, D.: Aid Allocation and Poverty Reduction, Eur. Econ. Rev., 46, 1475-1500, 2002.

Collins, S. L., Carpenter, S. R., Swinton, S. M., Orenstein, D. E., Childers, D. L., Gragson, T. L., Grimm, N. B., Grove, J. M., Harlan, S. L., Kaye, J. P., Knapp, A. K., Kofinas, G. P., Magnuson, J. J., McDowell, W. H., Melack, J. M., Ogden, L. A., Robertson, G. P., Smith, M. D., and Whitmer, A. C.: An integrated conceptual framework for long-term social-ecological research, Front. Ecology Environ., 9, 351-357, 2011.

Conrad, K.: Computable General Equilibrium Models in Environmental and Resource Economics, in: The International Yearbook of Environmental and Resource Economics 2002/2003: A Survey of Current Issues, edited bY: Tietenberg, T. and Folmer, H., Edward Elgar Publishing Ltd, Cheltenham, UK, 2003

Costanza, R., Leemans, R., Boumans, R., and Gaddis, E.: Integrated Global Models, in: Sustainability or Collapse: An Integrated History and future Of People on Earth, Dahlem Workshop Report 96, edited by: Costanza, R., Graumlich, L. J., and Steffen, W., MIT press, Cambridge, MA, 417-446, 2007.
Cui, X., Graf, H.-F., Langmann, B., Chen, W. W., and Huang, R.: Climate impacts of anthropogenic land use changes on the Tibetan Plateau, Global Planet. Change, 54, 33-56, 2006.

Dalin, C., Konar, M., Hanasaki, N., Rinaldo, A., and RodriguexIturbe, I.: Evolution of the global water trade network, P. Natl. Acad. Sci., 109, 5989-5994, 2012.

Davin, E. L. and de Noblet-Ducoudre, N.: Climatic Impact of Global-Scale Deforestation: Radiative versus Nonradiative Processes, J. Climate, 23, 97-112, doi:10.1175/2009JCLI3102.1, 2010.

Davin, E. L., de Noblet-Ducoudre, N., and Friedlingstein, P.: Impact of land cover change on surface climate: Relevance of the radiative forcing concept, Geophys. Res. Lett., 34, L13702, doi:10.1029/2007GL029678, 2007.

De Chazal, J. and Rounsevell, M. D. A.: Land use and climate change within assessments of biodiversity loss: a review, Global Environ. Change, 19, 306-315, 2009.

de Noblet-Ducoudré, N., Boisier, J.-P., Pitman, A., Bonan, G. B., Brovkin, V., Cruz, F., Delire, C., Gayler, V., van den Hurk, B. J. J. M., Lawrence, P. J., van der Molen, M. K., Müller, C., Reick, C., Strengers, B. J., and Voldoire, A.: Determining robust impacts of land-use induced land-cover changes on surface climate over North America and Eurasia; Results from the first set of LUCID experiments, J. Climate, 25, 3261-3281, doi:10.1175/JCLID-11-00338.1, 2012.

Eboli, F., Parrado, R., and Roson, R.: Climate Change Feedback on Economic Growth: Explorations with a Dynamic General Equilibrium Model, Environ. Develop. Econ., 15, 515-533, 2010.

Ellis, E. C., Neerchal, N., Peng, K., Xiao, H. S., Wang, H., Yan, Z., Li, S. C., Wu, J. X., Jiao, J. G., Ouyang, H., Cheng, X., and Yang, L. Z.: Estimating long-term changes in China's village landscapes, Ecosystems, 12, 279-297, 2009.

Evans, T. P. and Kelley, H.: Assessing the transition from deforestation to forest regrowth with an agent-based model of land cover change for south-central Indiana (USA), Geoforum, 39, 819-832, 2008.

Evans, T. P., Ostrom, E., and Gibson, C.: Scaling Issues with social data in integrated assessment modeling, Integr. Assess., 3, 135150, 2003.

Evans, T. P., Phanvilay, K., Fox, J., and Vogler, J.: An agent-based model of agricultural innovation, land-cover change and household inequality: The transition from swidden cultivation to rubber plantations in Laos PDR, J. Land Use Sci., 6, 151-173, 2011.

Fagiolo, G., Reyes, J., and Schiavo, S.: World Trade Web: Topological Properties, Dynamics and Evolution, Phys. Rev. E, 036115, 1-19, 2009.

FAO: Food Price Index, http://www.fao.org/worldfoodsituation/ wfs-home/foodpricesindex/en/ (last access: January 2013), 2012.

Filatova, T., Parker, D. C., and van der Veen, A.: Agent-based urban land markets: Agent's pricing behavior, land prices and urban land use change, Journal of Artificial Societies and Social Simulation, 12, http://jasss.soc.surrey.ac.uk/12/1/3.html, 2009.

Finnigan, J., Grigg, N., and Brede, M.: Quantitative modelling of the human-Earth system, in: Negotiating Our Future: Living scenarios for Australia to 2050, edited by: Raupach, M. R., McMichael, A. J., Finnigan, J. J., Manderson, L., Walker, B. H., Vol. 2., Australian Academy of Science, 2012. 
Fischer, G., Shah, M., Tubiello, F. N., and van Velhuizen, H.: Socioeconomic and climate change impacts on agriculture: an integrated assessment, 1990-2080, Philos. T. Roy. Soc. B, 360, 2067-2083, doi:10.1098/rstb.2005.1744, 2005.

Foley, J. A., DeFries, R., Asner, G. P., Barford, C., Bonan, G., Carpenter, S. R., Chapin, F. S., Coe, M. T., Daily, G. C., Gibbs, H. K., Helkowski, J. H., Holloway, T., Howard, E. A., Kucharik, C. J., Monfreda, C., Patz, J. A., Prentice, I. C., Ramankutty, N., and Snyder, P. K.: Global Consequences of Land use, Science, 309, 570-574, doi:10.1126/science.1111772, 2005.

Forrester, J. W.: World dynamics, Wright-Allen Press, Cambridge, MA, USA, 1971.

Forster, P., Ramaswamy, V., Artaxo, P., Bernsten, T., Betts, R., Fahey, D. W., Haywood, J., Lean, J., Lowe, D. C., Myhre, G., Nganga, J., Prinn, R., Raga, G., Schulz, M., and Van Doorland, R.: Changes in Atmospheric Constituents and in Radiative Forcing, in: Climate change 2007: The Physical Science Basis, Contribution of Working Group I to the Fourth Assessment Report of the Intergovernmental Panel on Climate Change, edited by: Solomon, S., Qin, D., Manning, M., Chen, Z., Marquis, M., Avery, K. B., Tignor, M., and Miller, H. L., Cambridge University Press, Cambridge, UK and New York, NY, USA, 2007.

Friedlingstein, P., Cox, P., Betts, R., Bopp, L., Von Bloh, W., Brovkin, V., Cadule, P., Doney, S., Eby, M., Fung, I., Bala, G., John, J., Jones, C., Joos, F., Kato, T., Kawamiya, M., Knorr, W., Lindsay, K., Matthews, H. D., Raddatz, T., Rayner, P., Reick, C., Roeckner, E., Schnitzler, K. G., Schnur, R., Strassmann, K., Weaver, A. J., Yoshikawa, C., and Zeng, N.: Climate-carbon cycle feedback analysis: Results from the (CMIP)-M-4 model intercomparison, J. Climate, 19, 3337-3353, 2006.

Fulton, E. A., Finnigan, J. J., Adams, P., Bradbury, R., Pearman, G. I., Sewell, R., Steffen, W., and Syme, G. J.: Exploring Futures with Quantitative Models, in: Negotiating the Future, Vol 1, edited by: Raupach, M. R., McMichael, A. J., Finnigan, J. J., Manderson, L., and Walker, B. H., Australian Academy of Science, Canberra, 152-187, 2012.

Geist, H. and Lambin, E. (Eds.): Land use and Land-Cover Change: Local Processes And Global Impacts, Springer, 222 pp., 2006.

Germann, T. C., Kadau, K., Longini, I. M., and Macken, C. A.: Mitigation Strategies for Pandemic Influenza in the United States, P. Natl. Acad. Sci., 103, 5935-5940, doi:10.1073/pnas.0601266103, 2006.

Gerten, D., Lucht, W., Schaphoff, S., Cramer, W., and Wagner, W.: Hydrologic resilience of the terrestrial biosphere, Geophys. Res. Lett., 32, L21408, doi:10.21029/22005GL024247, 2005.

Godfray, H. C. J., Beddington, J. R., Crute, I. R., Haddad, L., Lawrence, D., Muir, J. F., Pretty, J., Robinson, S., Thomas, S. M., and Toulmin, C.: Food Security: The Challenge of Feeding 9 Billion People, Science, 327, 812-818, doi:10.1126/science.1185383, 2010.

Gornall, J., Betts, R., Burke, E., Clark, R., Camp, J., Willett, K., and Wiltshire, A.: Implications of climate change for agricultural productivity in the early twenty-first century, Philos. T. Roy. Soc. B, 365, 2973-2989, doi:10.1098/rstb.2010.0158, 2010.

Grimm, V., Berger, U., Bastiansen, F., Eliassen, S., Ginot, V., Giske, J., Goss-Custard, J., Grand, T., Heinz, S. K., Huse, G., Huth, A., Jepsen, J. U., Jørgensen, C., Mooij, W. M., Müller, B., Pe'er, G., Piou, C., Railsback, S. F., Robbins, A. M., Robbins, M. M., Rossmanith, E., Rüger, N., Strand, E., Souissi, S., Stillman, R. A.,
Vabø, R., Visser, U., and DeAngelis, D. L.: A standard protocol for describing individual-based and agent-based models, Ecol. Model., 198, 115-126, 2006

Guillem, E. E., Barnes, A. P., Rounsevell, M. D. A., and Renwick, A.: Refining perception-based farmer typologies with the analysis of past census data, J. Environ. Manage., 110, 226-235, 2012.

Happe, K., Kellermann, K., and Balmann, A.: Agent-based Analysis of Agricultural Policies: an Illustration of the Agricultural Policy Simulator AgriPoliS, its Adaptation and Behavior, Ecol. Soc., 11, 49, 2006.

Hersperger, A. M., Gennaio, M.-P., Verburg, P. H., and Bürgi, M.: Linking land change with driving forces and actors: four conceptual models, Ecol. Soc., 15, 1, 2010.

Hertel, T. W. (Ed.): Global trade analysis: modelling and applications, Cambridge University Press, 379 pp., 1997.

Hertel, T. W. and Villoria, N. B.: GEOSHARE: Geospatial Open Source Hosting of Agriculture, Resource \& Environmental Data for Discovery and Decision Making, White Paper, Purdue University, West Lafayette, IN, USA, 2012.

Hertel, T. W., Rose, S., and Tol, R. S. J. (Eds.): Economic Analysis of Land use in Global Climate Change Policy, Routledge, Abingdon, UK, 2009a.

Hertel, T. W., Lee, H.-L., Rose, S., and Sohngen, B.: Modeling Land use Related Greenhouse Gas Sources and Sinks and their Mitigation Potential, in: Economic Analysis of Land use in Global Climate Change Policy, edited by: Hertel, T. W., Rose, S., and Tol, R. S. J., Routledge, Abingdon, UK, $2009 \mathrm{~b}$.

Hertel, T. W., Golub, A. A., Jones, A. D., O'Hare, M., Plevin, R. J., and Kammen, D. M.: Effects of US Maize Ethanol on Global Land Use and Greenhouse Gas Emissions: Estimating MarketMediated Responses, Bioscience, 60, 223-231, 2010.

Holland, J. H.: Adaptation in natural and artificial systems, University of Michigan Press, Ann Arbor, 1975.

Houghton, R. A.: Revised estimates of the annual net flux of carbon to the atmosphere from changes in land use and land management 1850-2000, Tellus B, 55, 378-390, 2003.

Huang, Q., Parker, D., Sun, S., and Filatova, T.: Effects of agent heterogeneity in the presence of a land-market: a systematic test in an agent-based laboratory, Comput. Environ. Urban Syst., 41, 188-203, 2013.

Hulme, M.: Meet the humanities, Nat. Clim. Change, 1, 177-179, 2011.

Hunter, M. C. and Brown, D. G.: Spatial contagion: Gardening along the street in residential neighborhoods, Landscape Urban Plan., 105, 406-416, 2012.

Isham, J.: The effect of social capital on fertiliser adoption: Evidence from rural Tanzania, J. Afr. Econ., 11, 39-60, 2002.

Jakeman, A. J. and Letcher, R. A.: Integrated assessment and modelling: features, principles and examples for catchment management, Environ. Model. Softw., 18, 491-501, 2003.

Janssen, M.: Complexity and Ecosystem Management: The Theory and Practice of Multi-agent Approaches, Edward Elgar Publishers, Chettenham, UK, 2003.

Jones, N. A., Perez, P., Measham, T. G., Kelly, G. J., D’Aquino, P., Daniell, K., Dray, A., and Ferrand, N.: Evaluating participatory modeling: Developing a framework for cross-case analysis, Environ. Manage., 44, 1180-1195, 2009. 
Jongman, B., Ward, P. J., and Aerts, J. C. J. H.: Global exposure to river and coastal flooding: Long term trends and changes, Global Environ. Change, 22, 823-835, doi:10.1016/j.gloenvcha.2012.07.004, 2012.

Kala, J., Lyons, T. J., and Nair, U. S.: Numerical Simulations of the Impacts of Land-Cover Change on Cold Fronts in SouthWest Western Australia, Bound.-Lay. Meteorol., 138, 121-138, doi:10.1007/s10546-010-9547-3, 2011.

Lambin, E. F. and Geist, H. J.: Regional Differences in Tropical Deforestation, Environment, 45, 22-36, 2003.

Lambin, E. F. and Meyfroidt, P.: Global land use change, economic globalization, and the looming land scarcity, P. Natl. Acad. Sci., 108, 3465-3472, 2011.

Lambin, E. F., Geist, H. J., and Rindfuss, R. R.: Introduction: Local Processes with Global Impacts, edited by: Lambin, E. F. and Geist, H. J., Springer-Verlag, Berlin, Heidelberg, 2006.

Lawrence, P. J. and Chase, T. N.: Investigating the climate impacts of global land cover change in the community climate system model, Int. J. Climatol., 30, 2066-2087, 2010.

Le Quere, C., Raupach, M. R., Canadell, J. G., Marland, G., Bopp, L., Ciais, P., Conway, T. J., Doney, S. C., Feely, R. A., Foster, P., Friedlingstein, P., Gurney, K., Houghton, R. A., House, J. I., Huntingford, C., Levy, P. E., Lomas, M. R., Majkut, J., Metzl, N., Ometto, J. P., Peters, G. P., Prentice, I. C., Randerson, J. T., Running, S. W., Sarmiento, J. L., Schuster, U., Sitch, S., Takahashi, T., Viovy, N., van der Werf, G. R., and Woodward, F. I.: Trends in the sources and sinks of carbon dioxide, Nat. Geosci., 2, 831-836, doi:10.1038/ngeo1689, 2009.

Letourneau, A., Verburg, P. H., and Stehfest, E.: A land-use systems approach to represent land-use dynamics at continental and global scales, Environ. Model. Softw., 33, 61-79, 2012.

Lim, Y. K., Cai, M., Kalnay, E., and Zhou, L. M.: Observational evidence of sensitivity of surface climate changes to land types and urbanization, Geophys. Res. Lett., 32, L22712, doi:10.1029/2005gl024267, 2005.

Liverman, D. M. and Cuesta, R. M. R.: Human interactions with the Earth system: people and pixels revisited, Earth Surf. Proc. Land., 33, 1458-1471, 2008.

Lobell, D. B. and Bonfils, C.: The effect of irrigation on regional temperatures: A spatial and temporal analysis of trends in California, 1934-2002, J. Climate, 21, 2063-2071, doi:10.1175/2007jcli1755.1, 2008

Lobell, D. B., Burke, M. B., Tebaldi, C., Mastrandrea, M. D., Falcon, W. P., and Naylor, R. L.: Prioritizing climate change adaptation needs for food security in 2030, Science, 319, 607-610, 2008.

Lobell, D. B., Schlenker, W., and Costa-Roberts, J.: Climate Trends and Global Crop Production Since 1980, Science, 333, 616-620, doi:10.1126/science.1204531, 2011.

Löfgren, H. and Robinson, S.: To trade or not to trade: nonseparable farm household models in partial and general equilibrium, TMD discussion paper no. 37, International Food Policy Research Institute, Washington, D.C., 1999.

Lotze-Campen, H., Mueller, C., Bondeau, A., Rost, S., Popp, A., and Lucht, W.: Global food demand, productivity growth, and the scarcity of land and water resources: A spatially explicit mathematical programming approach, Agricult. Econ., 39, 325-338, 2008.
Lubowski, R. N., Plantinga, A. J., and Stavins, R. N.: What Drives Land-Use Changes in the United States? A National Analysis of Landowner Decisions, Land Econ., 84, 529-550, 2008.

Lysenko, M. and D'Souza, R. M.: A Framework for Mega-scale Agent Based Model Simulations on Graphics Processing Units, J. Art. Soc. Social Simul., 11, 10, 2008.

Mackey, B., Prentice, C. I., Steffen, W., House, J. I., Lindenmayer, D., Keith, H., and Berry, S.: Untangling the confusion around land carbon science and climate change mitigation policy, Nat. Clim. Change, 3, 552-557, 2013.

Magliocca, N., Safirova, E., McConnell, V., and Walls, M.: An economic agent based model of coupled housing and land markets (CHALMS), Comput. Environ. Urban Syst., 35, 183-191, 2011.

Mahrt, L.: The bulk aerodynamic formulation over heterogeneous surfaces. Bound.-Lay. Meteorol., 78, 87-119, 1996.

Manson, S. M.: Bounded rationality in agent-based models: Experiments with evolutionary programs, Int. J. Geogr. Inf. Sci., 20, 991-1012, 2006.

Matthews, R. B., Gilbert, N. G., Roach, A., Polhill, J. G., and Gotts, N. M.: Agent-based land use models: a review of applications, Landscape Ecol., 22, 1447-1459, doi:10.1007/s10980007-9135-1, 2007.

May, R. M., Levin, S. A., and Sugihara, G:. Ecology for bankers, Nature, 451, 893-895, 2008.

McAllister, R. R. J., Tisdell, J. G., Reeson, A. F., and Gordon, I. J.: Economic behavior in the face of resource variability and uncertainty, Ecol. Soc., 16, 6, 2011.

Meijl, H. V., van Rheenen, T., Tabeau, A., and Eickhout, B.: The impact of different policy environments on agricultural land use in Europe, Agr. Ecosyst. Environ., 114, 21-38, 2006.

Melillo, J. M., Reilly, J. M., Kicklighter, D. W., Gurgel, A. C., Cronin, T. W., Paltsev, S., Felzer, B. S., Wang, X., Sokolov, A. P., and Schlosser, C. A.: Indirect Emissions from Biofuels: How Important?, Science, 5958, 1397-1399, doi:10.1126/science.1180251, 2009.

Melnikov, N., O’Neill, B. C., and Dalton, M. G.: Accounting for household heterogeneity in general equilibrium economic growth models, Energy Econ., 34, 1475-1483, 2012.

Messerli, P., Heinimann, A., and Epprecht, M.: Finding homogeneity in heterogeneity: a new approach to quantifying landscape mosaics developed for the Lao PDR, Human Ecol., 37, 291-304, 2009.

Meyfroidt, P.: Environmental cognitions, land change and socialecological feedbacks: an overview, J. Land Use Sci., 8, 341-367, doi:10.1080/1747423X.2012.667452, 2013.

Meyfroidt, P., Rudel, T. K., and Lambin, E. F.: Forest transitions, trade and the global displacement of land use, P. Natl. Acad. Sci., 107, 20917-20922, doi:10.1073/pnas.1014773107, 2010.

Minnesota Population Center: Integrated Public Use Microdata Series, International: Version 6.2 [Machine-readable database], University of Minnesota, Minneapolis, 2013.

Moran, E. F.: Environmental social science: human-environment interactions and sustainability, John Wiley \& Sons, Chichester, UK, 2010.

Murray-Rust, D., Dendoncker, N., Dawson, T., Acosta-Michlik, L., Karali, E., Guillem, E., and Rounsevell, M. D. A.: Conceptualising the analysis of socio-ecological systems through ecosystem services and agent based modelling, J. Land Use Sci., 6, 83-99, 2011. 
Nassauer, J. I., Wang, Z., and Dayrell, E.: What will the neighbors think? Cultural norms and ecological design, Landscape Urban Plan., 92, 282-292, 2009.

Newth, D. and Gunasekera, D.: Climate Change and the Effects of Dengue upon Australia: An Integrated Analysis of Health Impacts and Costs, IOP Conference Series: Earth and Environmental Science, Vol. 11, doi:10.1088/1755-1315/11/1/012020, 2010.

Nolan, J., Parker, D., and van Kooten, G. C.: An Overview of Computational Modeling in Agricultural and Resource Economics, Can. J. Agr. Econ., 57, 417-429, 2009.

NRC: Advancing Land Change Modeling: Needs and Research Requirements, Board on Earth Sciences and Resources, National Academies Press, Washington, D.C., 2013.

Pahl-Wostl, C:. Polycentric Integrated Assessment, Integr. Assess., 3, 220-232, 2002.

Pahl-Wostl, C., Sendzimir, J., Jeffrey, P., Aerts, J. C. J. H., Berkamp, G., and Cross, K.: Managing change toward adaptive water management through social learning, Ecol. Soc., 12, 5, 2007.

Pant, H. M.: Global Trade and Environment Model (GTEM): A computable general equilibrium model of the global economy and environment, Australian Bureau of Agricultural and Resource Economics, Canberra, 2002.

Parker, D. C. and Filatova, T.: A theoretical design for a bilateral agent-based land market with heterogeneous economic agents, Comput. Environ. Urban Syst., 32, 454-463, 2008.

Parker, D. C., Manson, S. M., Janssen, M. A., Hoffmann, M. J., and Deadman, P.: Multi-agent systems for the simulation of land use and land-cover change: A review, Ann. Assoc. Am. Geogr., 93, 314-337, 2003.

Parker, D. C., Hessl, A., and Davis, S. C.: Complexity, land use modeling, and the human dimension: Fundamental challenges for mapping unknown outcome spaces, Geoforum, 39, 789-804, 2008.

Perez, P.: Agents, Idols, and Icons, in: Complex Science for a Complex World, Exploring Human Ecosystems with Agents, edited by: Perez, P. and Batten, D., ANU E Press, Canberra, Australia, 27-56, 2006.

Pielke Sr., R. A., Pitman, A., Niyogi, D., Mahmood, R., McAlpine, C., Hossain, F., Goldewijk, K. K., Nair, U., Betts, R., Fall, S., Reichstein, M., Kabat, P., and de Noblet, N.: Land use/land cover changes and climate: modeling analysis and observational evidence, Interdis. Rev. Clim. Change, 2, 828-850, doi:10.1002/wcc.144, 2011.

Piorr, A., Ungaro, F., Ciancaglini, A., Happe, K., Sahrbacher, A., Sattler, C., Uthes, S., and Zander, P.: Integrated assessment of future CAP policies: land use changes, spatial patterns and targeting, Environ. Sci. Policy, 12, 1122-1136, 2009.

Pitman, A. J., de Noblet-Ducoudré, N., Cruz, F. T., Davin, E. L., Bonan, G. B., Brovkin, V., Claussen, M., Delire, C., Ganzeveld, L., Gayler, V., van den Hurk, B. J. J. M., Lawrence, P. J., van der Molen, M. K., Müller, C., Reick, C. H., Seneviratne, S. I., Strengers, B. J., and Voldoire, A.: Uncertainties in climate responses to past land cover change: First results from the LUCID intercomparison study, Geophys. Res. Lett., 36, L14814, doi:10.1029/2009g1039076, 2009.

Polhill, J. G., Gotts, N. M., and Law, A. N. R.: Imitative versus nonimitative strategies in a land use simulation, Cybernet. Syst., 32, 285-307, 2001.
Pontius, R., Boersma, W., Castella, J.-C., Clarke, K., de Nijs, T., Dietzel, C., Duan, Z., Fotsing, E., Goldstein, N., Kok, K., Koomen, E., Lippitt, C., McConnell, W., Mohd Sood, A., Pijanowski, B., Pithadia, S., Sweeney, S., Trung, T., Veldkamp, A., and Verburg, P.: Comparing the input, output, and validation maps for several models of land change, Ann. Reg. Sci., 42, 11-37, 2008.

Porkka, M., Kummu, M., Siebert, S., and Flörke, M.: The role of virtual water flows in physical water scarcity: The case of Central Asia, Int. J. Water Resour. Develop., 28, 453-474, doi:10.1080/07900627.2012.684310, 2012.

Rausch, S., Metcalf, G. E., and Reilly, J. M.: Distributional impacts of carbon pricing: A general equilibrium approach with micro-data for households, Energy Econ., 33, S20-S33, doi:10.1016/j.eneco.2011.07.023, 2011.

Reenberg, A.: Land system science: handling complex series of natural and socio-economic processes, J. Land Use Sci., 4, 1-4, 2009.

Rindfuss, R. R., Walsh, S. J., Mishra, V., Fox, J., and Dolcemascolo, G. P.: Linking household and remotely sensed data, methodological and practical problems, edited by: Fox, J., Rindfuss, R. R., Walsh, S. J., and Mishra, V., Kluwer Academic Publishers, Boston, 2003.

Robinson, D. T. and Brown, D. G.: Evaluating the effects of land use development policies on ex-urban forest cover: An integrated agent-based GIS approach, Int. J. Geogr. Inf. Sci., 23, 12111232, 2009.

Robinson, D. T., Brown, D. G., Parker, D. C., Schreinemachers, P., Janssen, M. A., Huigen, M., Wittmer, H., Gotts, N., Promburom, P. Irwin, E., Berger, T., Gatzweiler, F., and Barnaud, C.: Comparison of empirical methods for building agent-based models of land and resource use, J. Land Use Sci., 2, 31-55, 2007.

Rothman, D. S., van Bers, C., Bakkes, J., and Pahl-Wostl, C.: How to make global assessments more effective: lessons from the assessment community, Curr. Opin. Environ. Sustain., 1, 214-218, 2009.

Rotmans, J. and Asselt, M.: Integrated assessment: A growing child on its way to maturity, Climatic Change, 34, 327-336, 1996.

Rounsevell, M. D. A. and Arneth, A.: Representing human behaviour and decisional processes in land system models as an integral component of the Earth system, Global Environ. Change, 21, 840-843, 2011.

Rounsevell, M. D. A., Annetts, J. E., Audsley, E., Mayr, T., and Reginster, I.: Modelling the spatial distribution of agricultural land use at the regional scale, Agr. Ecosyst. Environ., 95, 465-479, 2003.

Rounsevell, M. D. A., Reginster, I., Araújo, M. B., Carter, T. R., Dendoncker, N., Ewert, F., House, J. I., Kankaanpää, S., Leemans, R., Metzger, M. J., Schmit, C., Smith, P., and Tuck, G.: A coherent set of future land use change scenarios for Europe, Agr. Ecosys. Environ., 114, 57-68, 2006.

Rounsevell, M. D. A., Robinson, D., and Murray-Rust, D.: From actors to agents in socio-ecological systems models, Philos. T. Roy. Soc. B, 367, 259-269, 2012.

Rudel, T. K.: Meta-analyses of case studies: A method for studying regional and global environmental change, Global Environ. Change, 18, 18-25, 2008.

Schaldach, R. and Priess, J. A.: Integrated Models of the Land System: A Review of Modelling Approaches on the Regional to Global Scale, Living Rev. Landsc. Res., 2, 1, 2008. 
Schaldach, R., Alcamo, J., Koch, J., Koelking, C., Lapola, D. M., Schungel, J., and Preiss, J. A.: An integrated approach to modelling land-use change on continental and global scales, Environ. Model. Softw., 26, 1041-1051, doi:10.1016/j.envsoft.2011.02.013, 2011.

Schreinemachers, P., Potchanasin, C., Berger, T., and Roygrong, S.: Agent-based modeling for ex ante assessment of tree crop innovations: litchis in northern Thailand, Agricult. Econ., 41, 519536, 2010.

Schröter, D., Cramer, W., Leemans, R., Prentice, I. C., Arnell, A. W., Araújo, M. B., Bondeau, A., Bugmann, H., Carter, T., de la Vega-Leinert, A. C., Erhard, M., Ewert, F., Fritsch, U., Friedlingstein, P., Glendining, M., Gracia, C. A., Hickler, T., House, J., Hulme, M., Kankaanpää, S., Klein, R. J. T., Lavorel, S., Lindner, M., Liski, J., Metzger, M. J., Meyer, J., Mitchell, T., Morales, P., Reidsma, P., Pla, E., Pluimers, J., Pussinen, A., Reginster, I., Rounsevell, M., Sánchez, A., Sabaté, S., Sitch, S., Smith, B., Smith, J., Smith, P., Sykes, M. T., Thonicke, K., Thuiller, W., Tuck, G., van der Werf, G., Vayreda, J., Wattenbach, M., Wilson, D. W., Woodward, F. I., Zaehle, S., Zierl, B., Zudin, S., AcostaMichlik, L., Moreno, J. M., Espiñeira, G. Z., Mohren, F., Bakker, M., and Badeck, F.: Ecosystem service supply and vulnerability to global change in Europe, Science, 310, 1333-1337, 2005.

Schubert, S. D., Suarez, M. J., Pegion, P. J., Koster, R. D., and Bacmeister, J. T.: On the cause of the 1930s Dust Bowl, Science, 303, 1855-1859, doi:10.1126/science.1095048, 2004.

Schweitzer, F., Fagiolo, G., Sornette, D., Vego-Redondo, F., Vespignani, A., and White, D. R.: Economic Networks: the New Challenges, Science, 325, 422-425, 2009.

Seto, K. C., Reenberg, A., Boone, C. G., Fragkias, M., Haase, D., Langanke, T., Marcotullio, P., Munroe, D. K., Olah, B., and Simon, D.: Urban land teleconnections and sustainability, P. Natl. Acad. Sci., 109, 7687-7692, 2012

Sitch, S., Brovkin, V., von Bloh, W., van Vuuren, D., Assessment, B., and Ganopolski, A.: Impacts of future land cover changes on atmospheric $\mathrm{CO}_{2}$ and climate, Global Biogeochem. Cy., 19, GB2013, doi:10.1029/2004GB002311, Gb2013, 2005.

Smajgl, A., Brown, D. G., Valbuena, D., and Huigen, M. G. A.: Empirical characterisation of agent behaviours in socioecological systems, Environ. Model. Softw., 26, 837-844, 2011.

Sokolov, A. P., Schlosser, C. A., Dutkiewicz, S., Paltsev, S., Kicklighter, D. W., Jacoby, H. D., Prinn, R. G., Forest, C. E., Reilly, J. M., Wang, C., Felzer, B. S., Sarofim, M. C., Scott, J., Stone, P. H., Melillo, J. M., and Cohen, J. B.: MIT Integrated Global System Model (IGSM) Version 2: Model Description and Baseline Evaluation, Report no. 124, July 2005, http://hdl.handle.net/ 1721.1/29789, MIT Joint Program on the Science and Policy of Global Change, Cambridge, MA, 2005.

Strengers, B. J., Mueller, C., Schaeffer, M., Haarsma, R. J., Severijns, C., Gerten, D., Schaphoff, S., van den Houdt, R. and Oostenrijk, R.: Assessing 20th century climate-vegetation feedbacks of land use change and natural vegetation dynamics in a fully coupled vegetation-climate model, Int. J. Climatol., 30, 2055-2065, 2010.

Tallis, H. M. and Kareiva, P.: Shaping global environmental decisions using socio-ecological models, Trends Ecol. Evol., 21, 562-568, 2006.

Tiebout, C.: A Pure Theory of Local Expenditures, J. Polit. Econ., 64, 416-424, 1956.
Tilman, D., Balzer, C., Hill, J., and Befort, B. L.: Global food demand and the sustainable intensification of agriculture, P. Natl. Acad. Sci., 108, 20260-20264, doi:10.1073/pnas.1116437108, 2011.

Turner II, B. L., Kasperson, R. E., Meyer, W. B., Dow, K. M., Golding, D., Kasperson, J. X., Mitchell, R. C., and Ratick, S. J.: Two types of global environmental change: Definitional and spatialscale issues in their human dimensions, Global Environ. Change, 1, 14-22, 1990.

Turner II, B. L., Lambin, E. F., and Reenberg, A.: The emergence of land change science for global environmental change and sustainability, P. Natl. Acad. Sci., 104, 20666-20671, 2007.

Valbuena, D., Verburg, P. H., and Bregt, A. K.: A method to define a typology for agent-based analysis in regional land use research, Agr. Ecosyst. Environ., 128, 27-36, 2008.

Valbuena, D., Bregt, A. K., McAlpine, C., Verburg, P. H., and Seabrook, L.: An agent-based approach to explore the effect of voluntary mechanisms on land use change: A case in rural Queensland, Australia, J. Environ. Manage., 91, 2615-2625, $2010 \mathrm{~b}$.

Valbuena, D., Verburg, P. H., Bregt, A. K., and Ligtenberg, A.: An agent-based approach to model land use change at a regional scale, Landscape Ecol., 25, 185-199, 2010a.

Van Asselen, S. and Verburg, P. H.: A Land System representation for global assessments and land use modeling, Global Change Biol., 18, 3125-3148, doi:10.1111/j.13652486.2012.02759.xvan, 2012.

Veldkamp, A., Verburg, P. H., Kok, K., de Koning, G. H. J., Priess, J., and Bergsma, A. R.: The need for scale sensitive approaches in spatially explicit land use change modeling, Environ. Monit. Assess., 6, 111-121, 2001.

Verburg, P. H., Eickhout, B., and van Meijl, H.: A multi-scale, multimodel approach for analyzing the future dynamics of European land use, Ann. Reg. Sci., 42, 57-77, 2008.

Verburg, P. H.: Simulating feedbacks in land use and land cover change models, Landscape Ecol., 21, 1171-1183, 2006.

Verburg, P. H. and Chen, Y. Q.: Multi-scale characterization of landuse patterns in China, Ecosystems, 3, 369-385, 2000.

Verburg, P. H., Schot, P., Dijst, M., and Veldkamp, A.: Land use change modelling: current practice and research priorities, GeoJournal, 61, 309-324, 2004.

Verburg, P. H., Neumann, K., and Nol, L.: Challenges in using land use and land cover data for global change studies, Global Change Biol., 17, 974-989, 2011.

Verburg, P. H., Koomen, E., Hilferink, M., Pérez-Soba, M., and Lesschen, J.-P.: An assessment of the impact of climate adaptation measures to reduce flood risk on ecosystem services, Landscape Ecol., 27, 473-486, doi:10.1007/s10980-012-9715-6, 2012.

Verburg, P. H., Zanden, E. M., van der Asselen, S., and Stehfest, E.: The representation of landscapes in global scale assessments of environmental change, Landsc. Ecol., 28, 1067-1080, doi:10.1007/s10980-10012-19745-10980, 2013.

Vliet, N., Mertz, O., Heinimann, A., Langanke, T., Pascual, U., Schmook, B., Adams, C., Schmidt-Vogt, D., Messerli, P., Leisz, S., Castella, J.-C., Jørgensen, L., Birch-Thomsen, T., Hett, C., Bech-Bruun, T., Ickowitz, A., Vu, K. C., Yasuyuki, K., Fox, J., Padoch, C., Dressler, W., and Ziegler, A. D.: Trends, drivers and impacts of changes in swidden cultivation in tropical 
forest-agriculture frontiers: A global assessment, Global Environ. Change, 22, 418-429, 2012.

Walters, B. B., Sabogal, C., Snook, L. K., and Almeida, E. D.: Constraints and opportunities for better silvicultural practice in tropical forestry: an interdisciplinary approach, Forest Ecol. Manage., 209, 3-18, 2005.

Wilbanks, T. J.: Geographic Scaling Issues in Integrated Assessments of Climate Change, Integr. Assess., 3, 100-114, 2002.

Wouterse, F., Deininger, K., Selod, H., Badiane, O., Swinnen, J., von Braun, L., and Zilberman, J.: Foreign Direct Investment in Land in West Africa; the Status Quo, Lessons from Other Regions, Implications for Research, http://www.ifpri.org/sites/ default/files/publications/wcaotn01.pdf, International Food Policy Research Institute, Washington, D.C., USA, 2011.
Young, O. R., Lambin, E. F., Alcock, F., Haberl, H., Karlsson, S. I., McConnell, W. J., Myint, T., Pahl-Wostl, C., Polsky, C., Ramakrishnan, P. S., Schroeder, H., Scouvart, M., and Verburg, P. H.: A portfolio approach to analyzing complex human-environment interactions: Institutions and land change, Ecol. Soc., 11, 31, 2006.

Zaehle, S., Ciais, P., Friend, A. D., and Prieur, V.: Carbon benefits of anthropogenic reactive nitrogen offset by nitrous oxide emissions, Nat. Geosci., 4, 601-605, doi:10.1038/NGEO1207, 2011.

Zellner, M. L., Page, S. E., Rand, W., Brown, D. G., Robinson, D. T., Nassauer, J., and Low, B.: The emergence of zoning policy games in exurban jurisdictions: Informing collective action theory, Land Use Policy, 26, 256-367, 2009.

Zellner, M. L., Riolo, R. L., Rand, W., Brown, D. G., Page, S. E., and Fernandez, L. E.: The problem with zoning: Nonlinear effects of interactions between location preferences and externalities on land use and utility, Enviro. Plan. B, 37, 408-428, 2010. 